U.S. Department of the Interior

U.S. Geological Survey

Prepared in cooperation with the

PUERTO RICO INFRASTRUCTURE FINANCING AUTHORITY

\title{
Sedimentation Survey of Lago Toa Vaca, Puerto Rico, June-July 2002
}

Scientific Investigations

Report 2004-5035

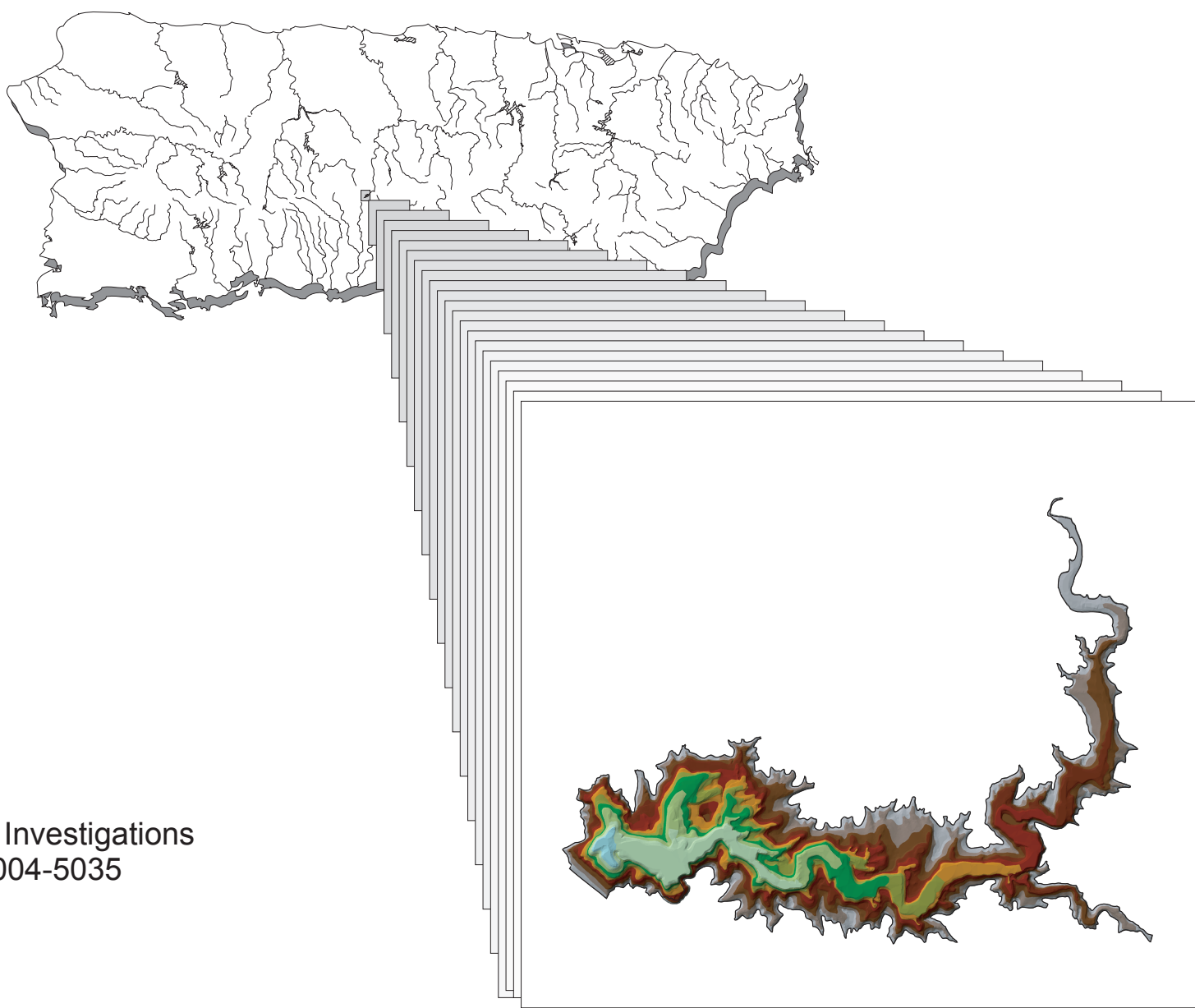




\section{Sedimentation Survey of Toa Vaca, Puerto Rico, June-July 2002}

By Luis R. Soler-López

Prepared in cooperation with the

PUERTO RICO INFRASTRUCTURE FINANCING AUTHORITY

Scientific Investigations Report 2004-5035 


\title{
U.S. Department of the Interior Gale A. Norton, Secretary
}

\author{
U.S. Geological Survey \\ Charles G. Groat, Director
}

U.S. Geological Survey, Reston, Virginia: 2004

For sale by U.S. Geological Survey, Information Services

Box 25286, Denver Federal Center

Denver, CO 80225

For more information about the USGS and its products:

Telephone: 1-888-ASK-USGS

World Wide Web: http://www.usgs.gov/

Any use of trade, product, or firm names in this publication is for descriptive purposes only and does not imply endorsement by the U.S. Government.

Suggested citation:

Soler-López, L.R., Sedimentation survey of Lago Toa Vaca, Puerto Rico, June-July 2002, U.S. Geological Survey Scientific Investigations Report 2004-5035, 32 p. 


\section{Contents}

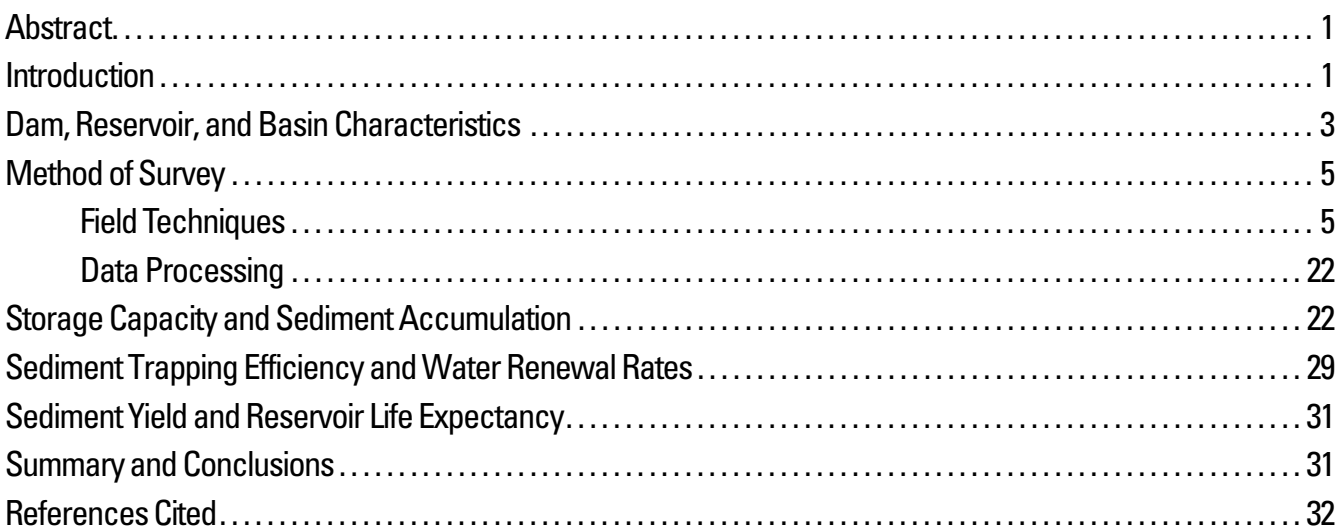

\section{Plates}

[In pocket]

1. Lago Toa Vaca, Puerto Rico, Bathymetry, 2002

2. Lago Toa Vaca, Puerto Rico, Topography, 1972

\section{Figures}

1-3. Map showing

1. Location of Lago Toa Vaca in the upper Río Jacaguas and Río Toa Vaca Basins, and areas served by the Juana Díaz Irrigation District in southern Puerto Rico ...................................................

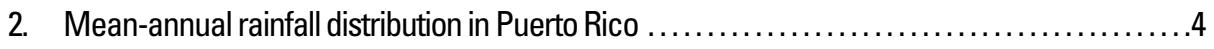

3. Lago Toa Vaca drainage area showing the reservoir shoreline and tributaries

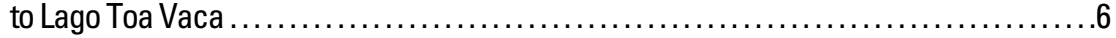

4. Aerial photograph of part of Lago Toa Vaca drainage area showing the location of the quarry. .

5-8. Map showing

5. Planned location of sounding lines for the 2002 bathymetric survey of Lago

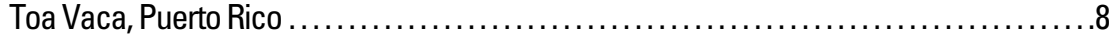

6. Actual survey sounding lines of the 2002 bathymetric survey of Lago Toa Vaca, Puerto Rico.

7. Triangulated irregular network (TIN) surface model of Lago Toa Vaca,

Puerto Rico, for 2002. 10

8. Reference longitudinal distance along the thalweg of Lago Toa Vaca, Puerto Rico. 
9-11. Graph showing

9. Selected cross sections generated from the TIN surface models of Lago

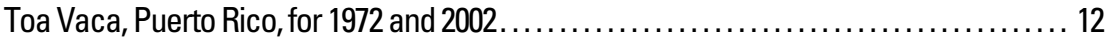

10. Longitudinal profiles generated from the TIN surface models along the

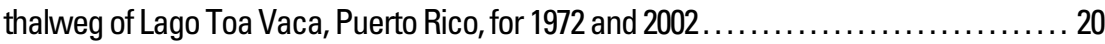

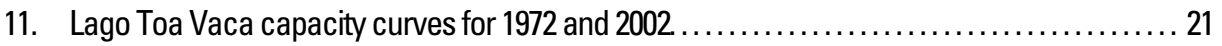

12. Aerial photograph of the Lago Toa Vaca dam area showing the approximate extent of the borrow area used in construction of the earthfill dam as shown in the Unites States Bureau of Reclamation plans.

13. Aerial photograph of the Lago Toa Vaca dam area showing the rock-source area and

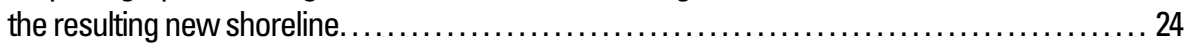

14. Front-view perspective of the rock-source area and drill marks visible during the 2002

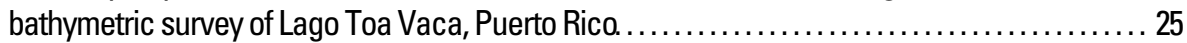

15. Map showing planned location of sounding lines for the 1985 bathymetric survey of Lago Toa Vaca, Puerto Rico ............................................. 26

16. Reservoir trapping efficiency as a function of the ratio between storage capacity and

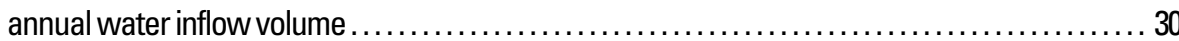

\section{Tables}

1. Principal characteristics of Lago Toa Vaca and Toa Vaca dam, Puerto Rico $\ldots \ldots \ldots \ldots \ldots \ldots \ldots . \ldots . \ldots$

2. Comparison of the 1972 topographic survey with the 2002 bathymetric survey of Lago Toa Vaca, Puerto Rico ................................................ 27

3. Storage capacity of Lago Toa Vaca, Puerto Rico, June-July $2002 \ldots \ldots \ldots \ldots \ldots \ldots \ldots \ldots \ldots \ldots \ldots \ldots \ldots \ldots \ldots$ 


\section{Conversion Factors, Datums, Acronyms, and Translations}

\begin{tabular}{lcl}
\hline Multiply & By & To obtain \\
\hline & Length & inch \\
millimeter & 0.03937 & foot \\
centimeter & 0.03281 & foot \\
meter & 3.281 & mile \\
kilometer & 0.6214 & \\
& Area & square foot \\
square meter & 10.76 & square mile \\
square kilometer & 0.3861 & acre \\
square kilometer & 247.1 & \\
& Volume & cubic foot \\
cubic meter & 35.31 & acre-foot \\
cubic meter & 0.0008107 & acre-foot \\
million cubic meters & 810.7 & \\
& Volume per unit time (includes flow) & cubic feet per second \\
cubic meter per second & 35.31 & gallon per minute \\
cubic meter per second & 15,850 & million gallons per day \\
cubic meter per second & 22.83 & \\
& Mass per area (includes sediment yield) & \\
megagram per square kilometer & 2.855 & ton per square mile \\
\hline
\end{tabular}

\section{Datums}

Horizontal Datum - Puerto Rico Datum, 1940 Adjustment

Sea level: In this report, "sea level" refers to the National Geodetic Vertical Datum of 1929

(NGVD of 1929)- a geodetic datum derived from a general adjustment of the first-order level nets of the United States and Canada, formerly called "Seal Level Datum of 1929".

\section{Acronyms used in this report}

$\begin{array}{ll}\text { BLASS } & \text { Bathymetric/Land Survey System } \\ \text { DGPS } & \text { Differential Global Positioning System } \\ \text { DO0 } & \text { Digital Orthophoto Ouadrangle } \\ \text { GIS } & \text { Geographic Information System } \\ \text { GPS } & \text { Global Positioning System } \\ \text { PRIFA } & \text { Puerto Rico Infrastructure Financing Authority } \\ \text { TIN } & \text { Triangulated Irregular Network } \\ \text { USGS } & \text { U.S. Geological Survey }\end{array}$

\section{Translations}

Spanish

English

Lago

Lake (in Puerto Rico, also reservoir)

Río

River 


\title{
Sedimentation Survey of Lago Toa Vaca, Puerto Rico, June-July 2002
}

\author{
By Luis R. Soler-López
}

\section{Abstract}

The Lago Toa Vaca dam is located in the municipality of Villalba in southern Puerto Rico, and is owned and operated by the Puerto Rico Aqueduct and Sewer Authority. Construction was completed in 1972 as the first phase of a multi-purpose project that contemplated four possible diversions from other basins to mitigate the rapid storage capacity loss of Lago Guayabal, located immediately downstream of the Toa Vaca dam. The latter phases of the intra-basin diversions were cancelled, and currently, the reservoir receives runoff from only 56.8 square kilometers of its drainage area.

Lago Toa Vaca reservoir when constructed was to be used for irrigation of croplands in the southern coastal plain. The reservoir had an original storage capacity of 68.94 million cubic meters. Sedimentation has reduced the storage capacity by only 7 percent between 1972 and 2002 to 64.08 million cubic meters. This represents a long-term sedimentation rate of about 162,000 cubic meters per year.

Based on the 2002 sedimentation survey, Lago Toa Vaca has a sediment trapping efficiency of about 98 percent and a drainage area-normalized sedimentation rate of about 3,086 cubic meters per square kilometer per year between 1972 and 2002. At the current long-term sedimentation rate the reservoir would lose its storage capacity by the year 2400 .

\section{Introduction}

The southern coastal plain of Puerto Rico has traditionally been used for agricultural purposes (fig. 1). Because rainfall along the southern coastal plain averages 900 millimeters per year (Calvesbert, 1970), a major irrigation infrastructure project to convey water for the cultivation of crops along this coastal plain was completed in 1914. The Lago Guayabal reservoir constituted the principal source of surface-water irrigation within the western half of the southern coastal plain. This reservoir was losing storage capacity rapidly, and after many efforts to restore storage capacity by dredging and installation of flashboards, managing authorities decided to construct the Toa Vaca dam on the Río Toa Vaca, the northeastern tributary of Lago Guayabal. The new dam was built to impound water from the Río Toa Vaca, Río Coamo, and Río Jacaguas located in the south-central part of the island, and to receive water transferred from the headwaters of the Río Grande de Arecibo, Río Grande de Manatí, and Río Saliente, located north of the insular hydrologic divide (Puerto Rico Water Resources Authority, 1967). However, after the completion of the Toa Vaca dam in 1972, the project of the intra-basin diversions was cancelled and currently the reservoir receives only the runoff from its 56.8 square-kilometer drainage basin. The construction of Lago Toa Vaca reservoir, nevertheless, has benefitted the immediate areas by: (1) reducing the rapid storage capacity loss of Lago Guayabal; (2) providing additional surface-water storage that otherwise would have been impossible to contain in Lago Guayabal; and (3) providing flood control protection to the population downstream of Lago Guayabal.

The Lago Toa Vaca was to be used primarily as a water source for irrigation in southern Puerto Rico. However, immediately after construction in 1972, its use was designated primarily for public-water supply purposes and its management was transferred from the Puerto Rico Electric Power Authority (PREPA) to the Puerto Rico Aqueduct and Sewer Authority (PRASA).

The U.S. Geological Survey (USGS), in cooperation with the Puerto Rico Infrastructure Financing Authority (PRIFA) conducted a bathymetric survey of Lago Toa Vaca during JuneJuly 2002. The bathymetric survey was conducted using a differential global positioning system (DGPS) interfaced to a depth sounder. The field data were then transferred into a geographic information system (GIS), which was used to determine the existing storage capacity, the sedimentation rates, sediment distribution, and to predict the useful life of the reservoir.

This report provides PRIFA and PRASA officials with the necessary information to more effectively manage the water resources of Lago Toa Vaca. Data from the 2002 bathymetric survey were compared with the 1972 pre-impoundment storage capacity of Lago Toa Vaca as defined from the 1:20,000 USGS Río Descalabrado topographic quadrangle. A high-resolution bathymetric survey was completed to define the historical longterm sedimentation rate, the storage capacity loss, and to provide an accurate bathymetric map for future reference. 


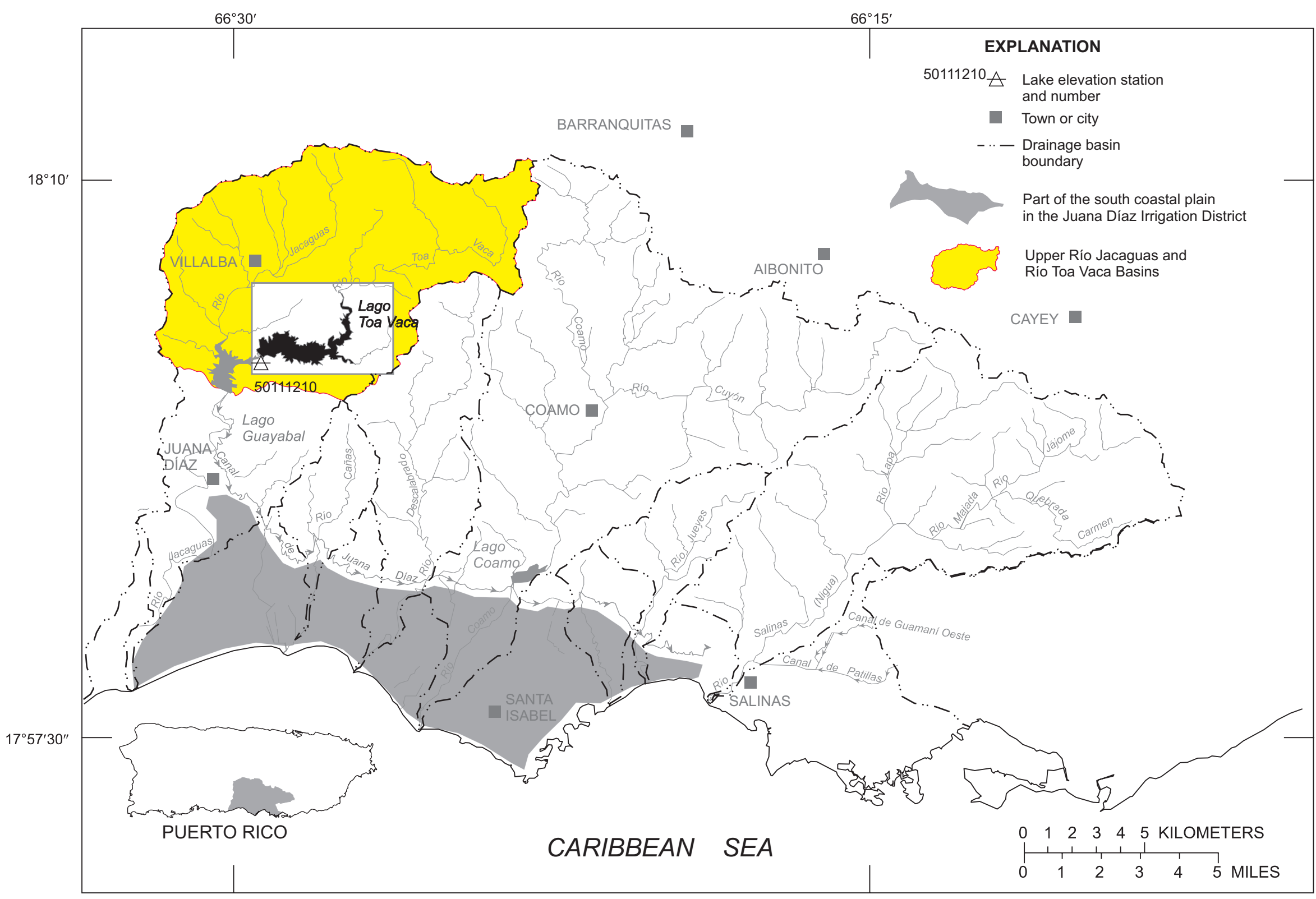

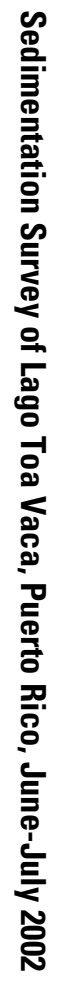

Figure 1. Location of Lago Toa Vaca in the upper Río Jacaguas and Río Toa Vaca Basins, and areas served by the Juana Díaz Irrigation District in southern Puerto Rico. 


\section{Dam, Reservoir, and Basin Characteristics}

The Lago Toa Vaca dam structure was completed in 1972. It is located on the Río Toa Vaca in the municipality of Villalba in southern Puerto Rico, about 5 kilometers north of Juana Díaz and about 4 kilometers south of Villalba (fig. 1). The reservoir has a drainage area of 56.8 square kilometers. Although the dam was originally designed to provide about 68.94 million cubic meters of water storage for irrigation of sugarcane crops in southern Puerto Rico, its principal use was changed in 1972 as an infrastructure improvement for public-water supply purposes (U.S. Department of Agriculture, 1987).

Lago Toa Vaca was to be a major part of the largest irrigation-water supply infrastructure project in southern Puerto Rico. Source waters were to include the area draining to Lago Toa Vaca and headwaters of the Río Coamo, Río Jacaguas, Río Grande de Arecibo, Río Grande de Manatí, and Río Saliente, and so was provided with the largest water storage capacity in Puerto Rico at the time of construction. However, the plans for the mega project were later abandoned.

The dam is an earthfill structure with a height of 65.53 meters above the original Toa Vaca river bed, a length of 530.35 meters, and has a spillway elevation of 154.83 meters above mean sea level. Flashboards were installed on top of three radial gates (with dimensions of 9.14 meters wide by 9.26 meters high) to raise the normal pool elevation of the reservoir to
164.90 meters above mean sea level. The spillway was designed to discharge 2,180 cubic meters per second at the maximum pool elevation of 166.48 meters above mean sea level. The outlet works of the dam are located at the right abutment and consist of a diversion inlet, an intake tower, an intake shaft, a circular tunnel, a gate chamber, an access house, and a flow meter.

Water for public use is withdrawn from the intake tower located 130 meters upstream from the dam, near the right bank. The tower has six intakes at different elevations. The lowest intake has an invert elevation of 121.00 meters above mean sea level, the next intake is at an invert elevation of 124.05 meters above mean sea level, and the remaining four intakes are spaced 9.14 meters apart. Part of this information and other characteristics of the Lago Toa Vaca dam are summarized in table 1 .

Mean-annual rainfall in the Lago Toa Vaca Basin is about 1,800 millimeters (Calvesbert, 1970) (fig. 2). The Caguabo and Humatas soils, with the moderate erosion hazard are the predominant soils in the basin. Slopes vary from 20 to 60 percent. The solum of the Caguabo series is 36 to 61 centimeters thick, and the Humatas series solum is 76 to 132 centimeters thick. Surface runoff in these soils is rapid, thus the moderate susceptibility to erosion (Gierbolini, 1979). The steep slopes, thickness of the solum and the climatic conditions all contribute to the high susceptibility of the basin to erosion and the consequent storage capacity loss of Lago Toa Vaca.

Table 1. Principal characteristics of Lago Toa Vaca and Toa Vaca dam, Puerto Rico (modified from the Puerto Rico Water Resources Authority, 1975).

Total length of dam, in meters

Maximum height of dam, in meters

Invert elevation of lower intake structure, in meters above mean sea level

Crest elevation of spillway structure, in meters above mean sea level

Normal pool elevation after the installation of flashboards, in meters above mean sea level

Reservoir length at normal pool elevation, in kilometers

Maximum discharge capacity, in cubic meters per second ${ }^{1}$

Drainage area at dam site, in square kilometers ${ }^{1}$

Reservoir surface area at elevation of 164.90 meters above mean sea level, in square kilometers

Maximum depth after reservoir impoundment, in meters

Maximum depth during the June-July 2002 bathymetric survey, in meters
530.35

164.90

6.75

$2,180.0$

56.8

3.22

54.90

54.00

\footnotetext{
${ }^{1}$ Puerto Rico Water Resources Authority, 1975.
} 


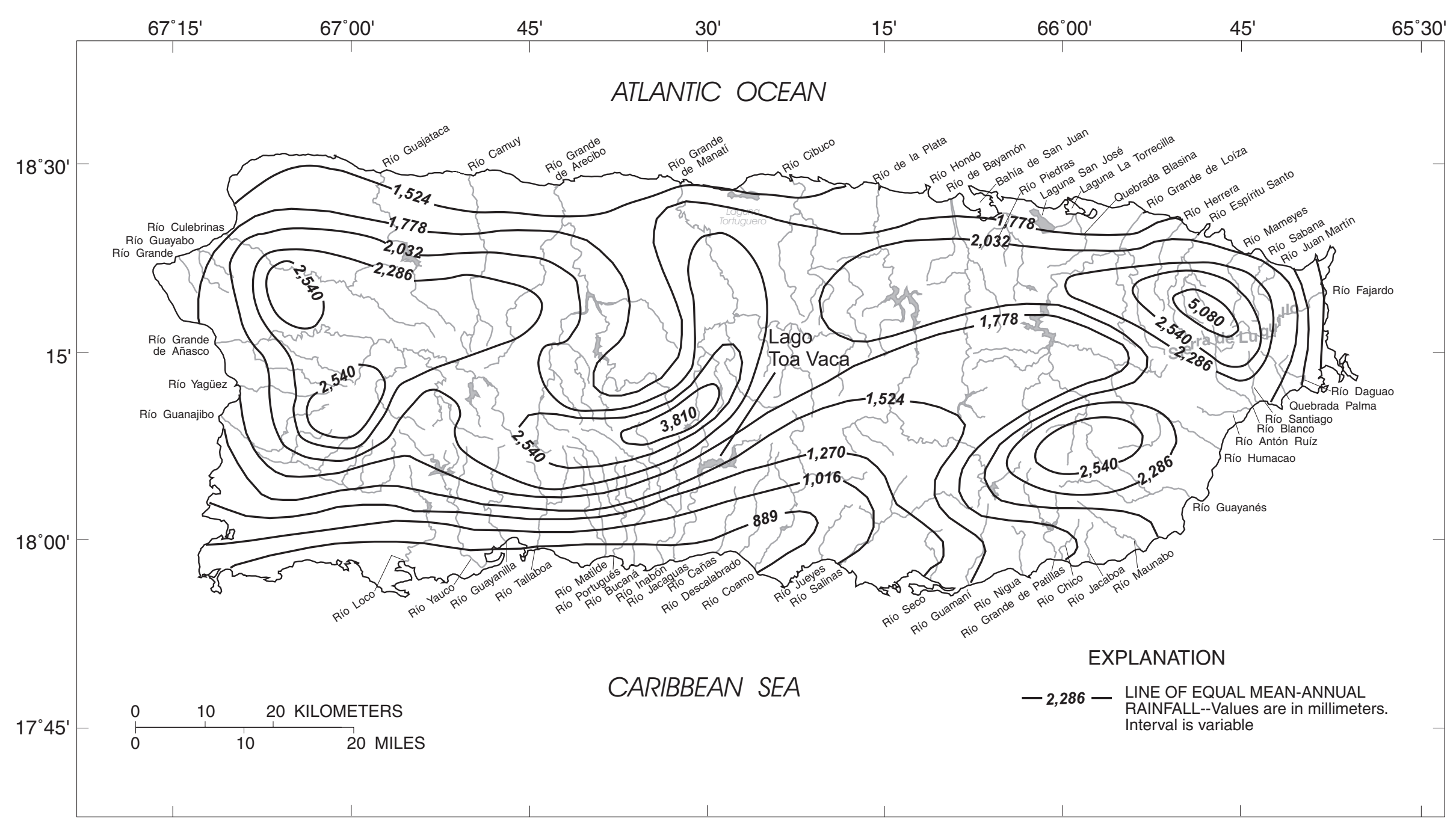

Figure 2. Mean-annual rainfall distribution in Puerto Rico (modified from Calvesbert, 1970). 
The Caguabo soils, for the most part, have remained in pasture, brush, with some shallow-rooted crops that include pigeon peas. The Humatas soils are typically planted with a wide variety of crops, including coffee, yams, plantains, and tanniers. Some areas are covered with native pasture (Gierbolini, 1979).

Human development in the basin as of 1995 has been minimal (fig. 3). However, some climatic and anthropogenic conditions within and around the basin, could be affecting the sediment yields from the Toa Vaca drainage area. There are intensively cultivated private croplands in the immediate periphery of the reservoir; wildfires are common, especially during the relatively dry months, which extend from February to July, and there is a quarry within the headwaters of the Río Toa Vaca drainage basin. This quarry, although originally outside of the Río Toa Vaca drainage basin, has progressively mined resources northward across the hydrologic divide and could be contributing to additional erosion within the basin (fig. 4).

\section{Method of Survey}

The 2002 bathymetric survey of Lago Toa Vaca involved planning, data collection, and data processing and analysis. An Arc/Info GIS was used to establish the survey lines and analyze the collected data. Survey lines were planned at a spacing of 50 meters, beginning at the dam and continuing upstream along the two branches of Lago Toa Vaca (fig. 5). Bathymetric data were collected during June-July 2002 using a depth sounder coupled to a DGPS that recorded the horizontal position of the survey boat. A geo-referenced digital map of the reservoir shoreline and planned survey lines were loaded into a portable personal (laptop) computer; these data served as the guide for bathymetric data collection.

The reservoir pool elevation was monitored at the continuous recording USGS lake-level station Lago Toa Vaca at damsite near Villalba, Puerto Rico, station number 50111210 (fig. 1). The pool elevation of Lago Toa Vaca was not at the crest of the top of the gates, therefore, the sounding data were adjusted using a time-elevation correction factor to represent depths at normal pool elevation of 164.90 meters above mean sea level.

A total of 17,345 data points (depth soundings) were collected over the entire reservoir while navigating along the planned survey lines (fig. 6). The depths along the cross sections were plotted, and 1-meter interval contour lines of equal depth were drawn from the shoreline to the deepest parts of the reservoir (plate 1). The procedure used to contour the reservoir bottom is explained further on in the Data Processing section. These contour lines were then converted into a triangulated irregular network (TIN) describing the reservoir bottom (fig. 7). The TIN represents the reservoir bottom surface model as thousands of adjoining triangles with $\mathrm{x}, \mathrm{y}$, and $\mathrm{z}$ coordinates assigned to all vertices (Environmental Systems Research Institute, Inc. 1992). The longitudinal distance of the reservoir along the central portion is shown on figure 8 . The original 1972 pre-impounded topography of the Lago Toa Vaca reservoir is shown on plate 2 . The GIS utilized the TIN to calculate the storage capacity and thickness of sediment accumulation. The 1972 reservoir storage was compared with the 2002 calculated storage capacity to obtain an estimate of the historical sediment accumulation rate and to estimate the useful life of the reservoir based on historical and current data.

Selected cross sections depicting the reservoir bottom from shore to shore, as well as longitudinal profiles of the reservoir bottom along the thalweg of Lago Toa Vaca were generated for 1972 and 2002 from their TIN surface models (figs. 9 and 10). The relation between pool elevation and reservoir storage capacity for 1972 and for 2002 was generated by calculating the reservoir volume at 1-meter elevation intervals and is shown in graphical form on figure 11.

\section{Field Techniques}

The bathymetric survey of Lago Toa Vaca was conducted during June-July, 2002. Data were collected using the bathymetric/land survey system (BLASS) developed by Specialty Devices, Inc. The system consists of two Novatel global positioning system (GPS) receivers coupled to a Depth Sounder model SDI-IDS Intelligent. The GPS receivers monitor the horizontal position of the survey boat while the depth sounder measures water depths. The GPS units were first used in static mode to establish a benchmark overlooking the reservoir. Satellite data were recorded simultaneously at the USGS District office benchmark (referred to as "USGS roof") (latitude $18^{\circ} 25^{\prime}$ N., longitude $66^{\circ} 06^{\prime} \mathrm{W}$.) and at a site overlooking the reservoir. The benchmark coordinates for "Toa Vaca 1" (latitude $18^{\circ} 06^{\prime} N$., longitude $66^{\circ} 27^{\prime} \mathrm{W}$.), were then calculated using the post-processing software CENTIPOINT. Although the new benchmark indicated a horizontal error of less than 10 centimeters, the coordinates listed previously are reported to the nearest minute. Once established, the "Toa Vaca 1 " benchmark was established as the reference station. One GPS unit was installed at the reference station; the other GPS unit was installed in the survey boat to be used as the mobile station. The GPS on board the survey boat independently calculated a position every second while receiving a set of correction signals from the reference station, converting the system into a DGPS. This combination maintained the data position accuracy within two meters. The bathymetric survey software HYPACK was used to navigate and to collect data. The software integrates the depth and position data, storing the $\mathrm{x}, \mathrm{y}$, (geographic locations) and $\mathrm{z}$ (depths) coordinates in a portable personal computer.

A total of 159 survey sounding lines were planned using the GIS (fig. 5); however, sediment accumulation, low pool elevation, and vegetation growth in riverine areas limited the data collection to only 114 cross sections (fig. 6). 


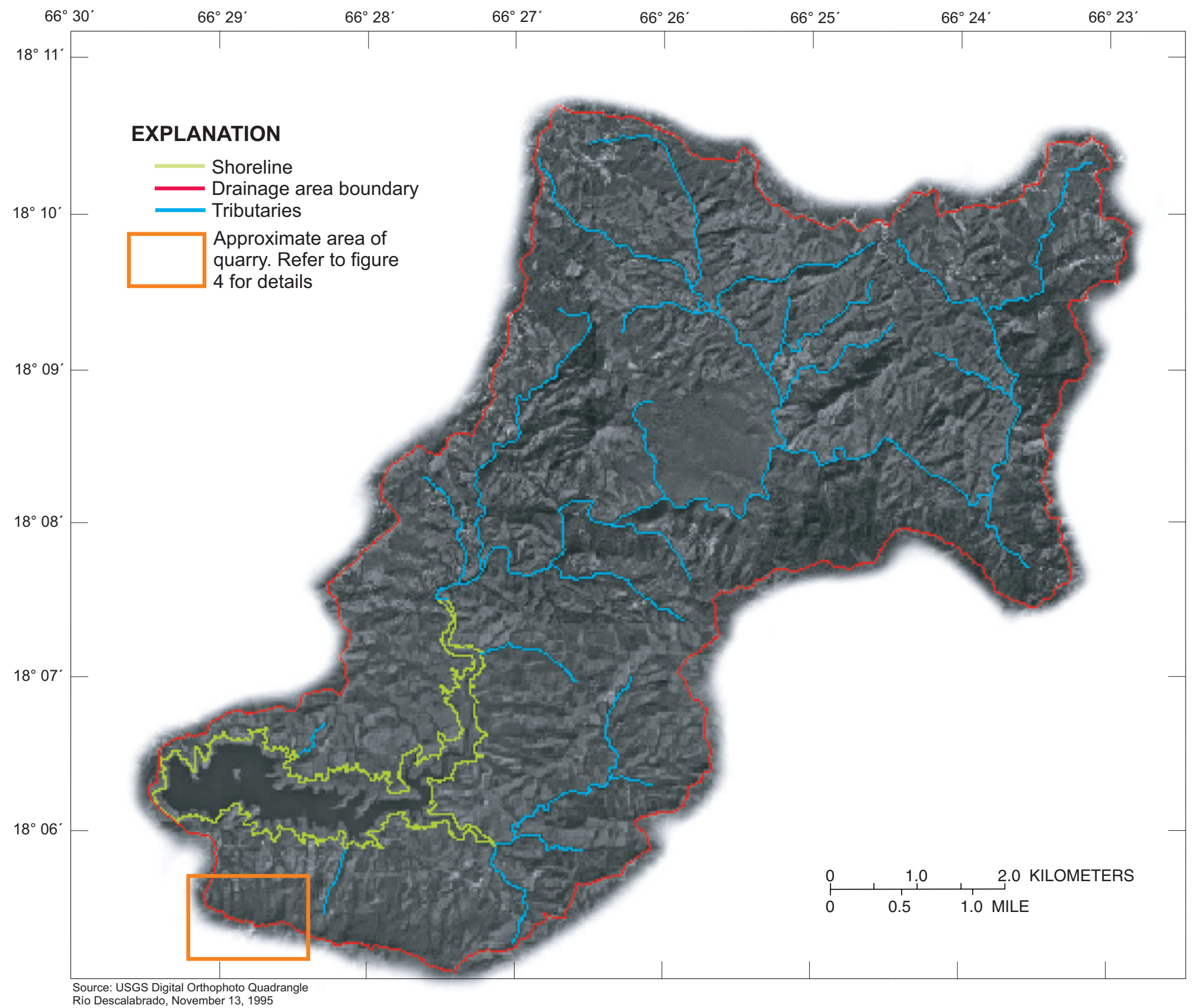

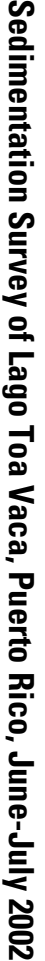

Figure 3. Lago Toa Vaca drainage area showing the reservoir shoreline and tributaries to Lago Toa Vaca. 


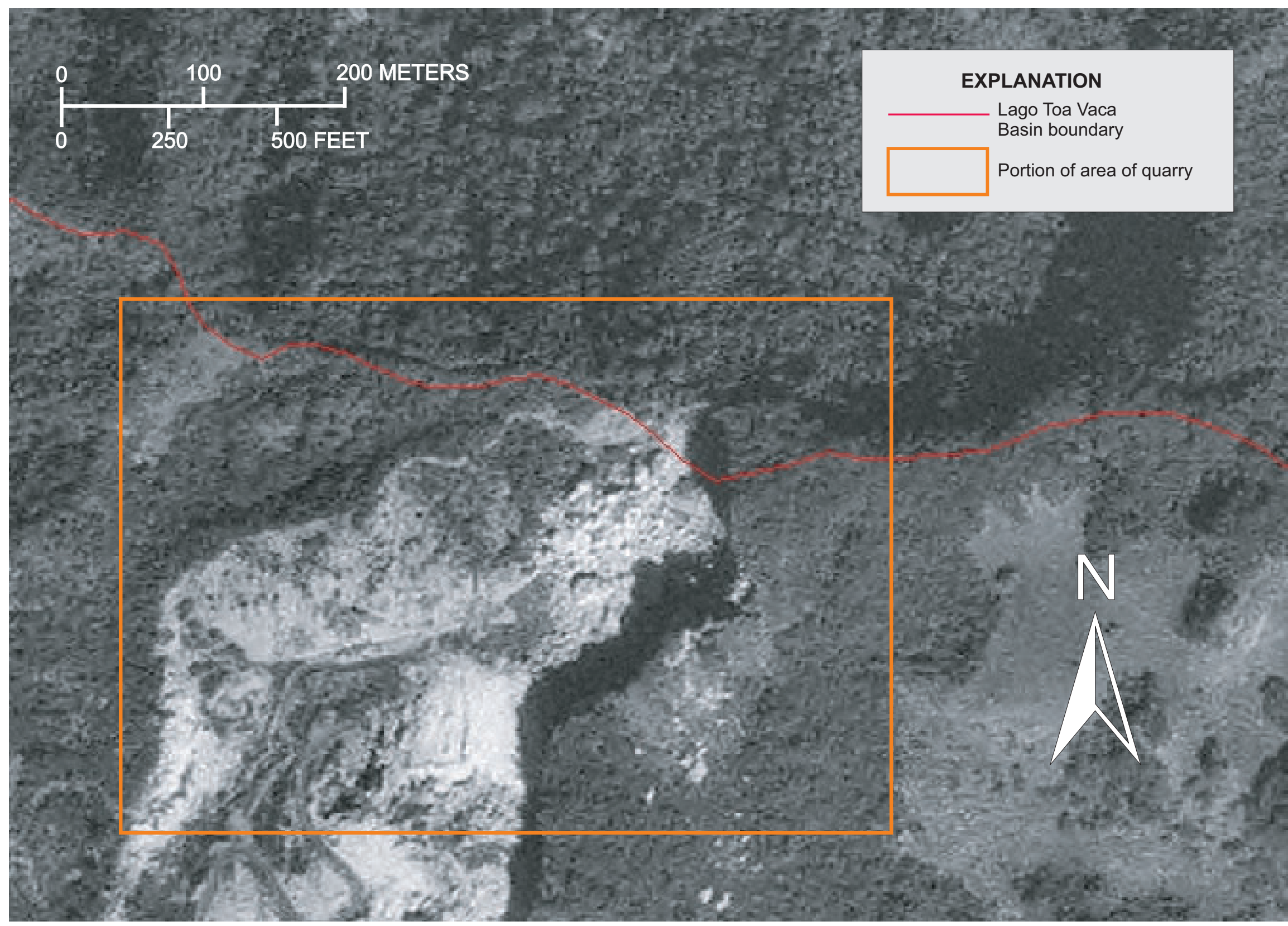

Figure 4. Aerial photograph of part of Lago Toa Vaca drainage area showing the location of the quarry. Note that the resource exploitation has altered the hydrologic divide boundary marked by a red line. (Photo taken on November 13, 1995.) 


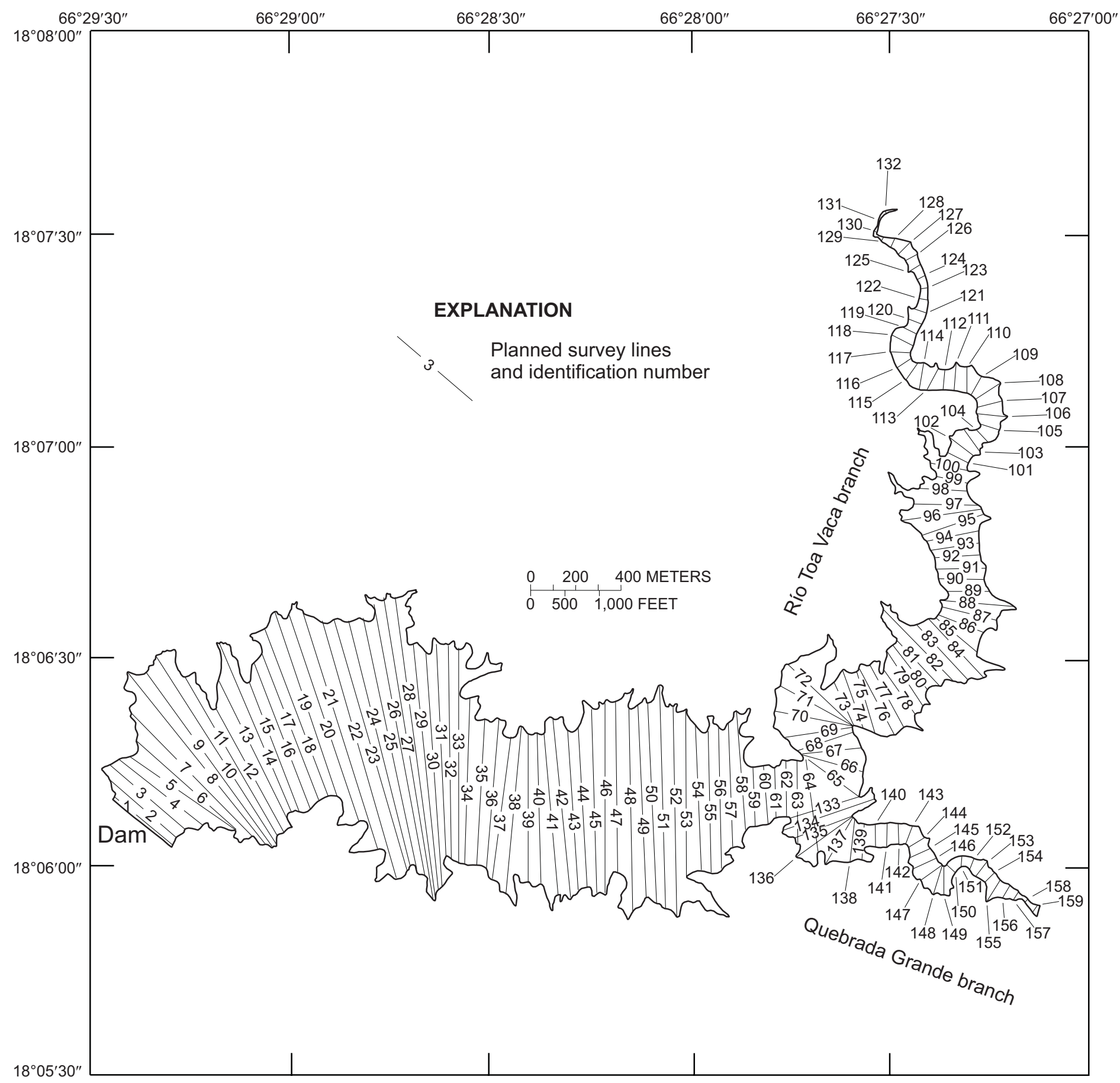

Figure 5. Planned location of sounding lines for the 2002 bathymetric survey of Lago Toa Vaca, Puerto Rico. 


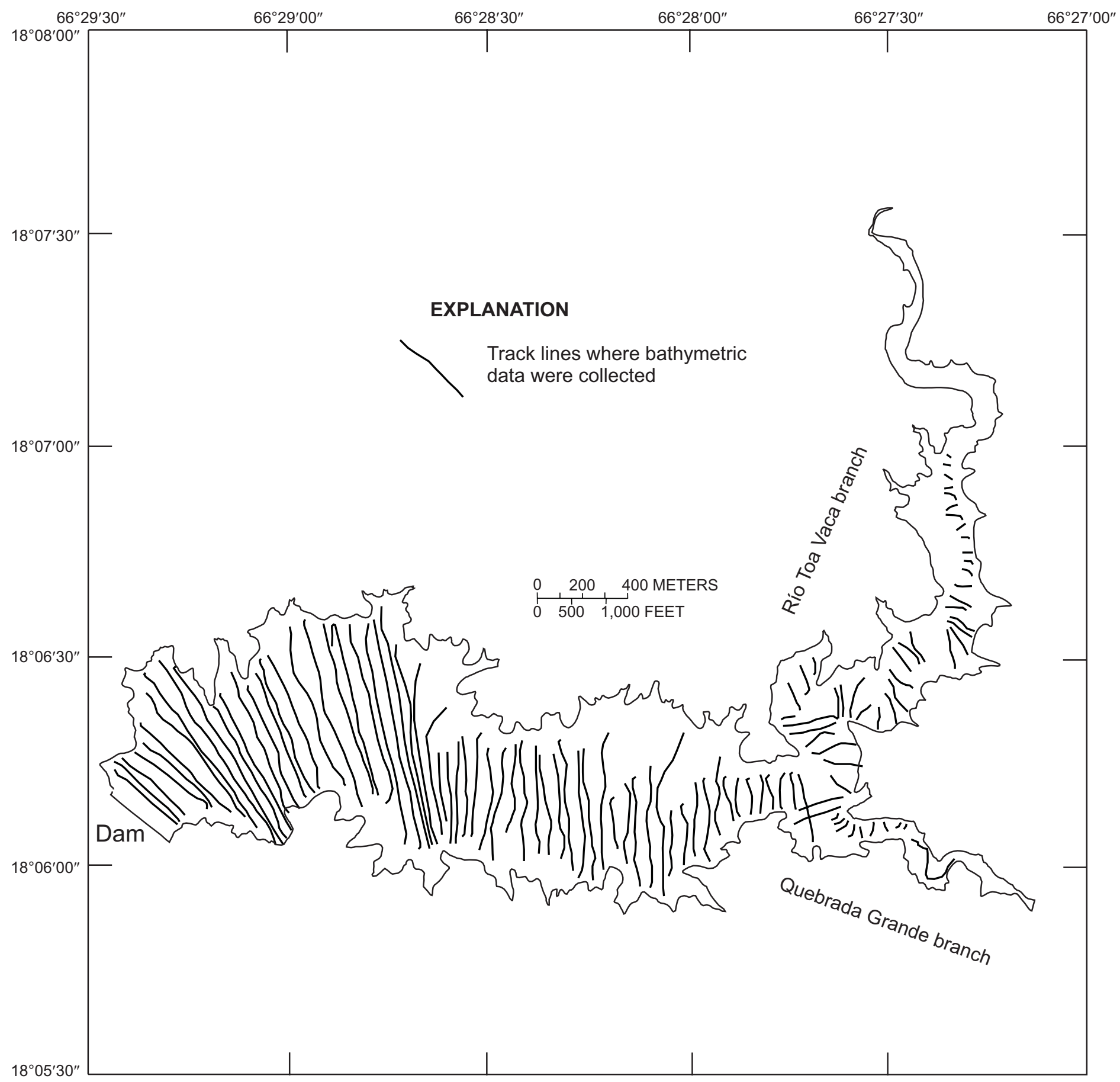

Figure 6. Actual survey sounding lines of the 2002 bathymetric survey of Lago Toa Vaca, Puerto Rico. 


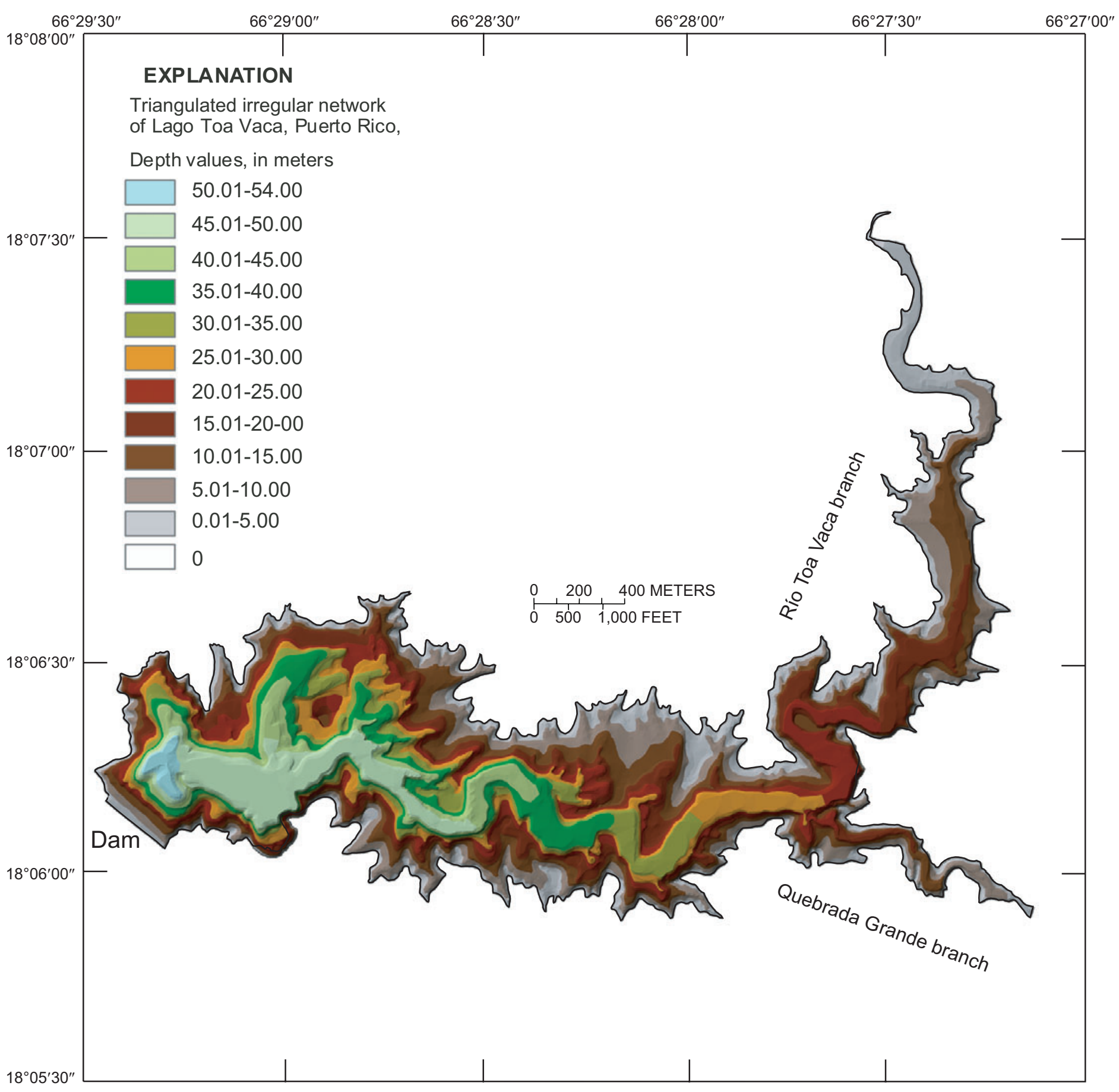

Figure 7. Triangulated irregular network (TIN) surface model of Lago Toa Vaca, Puerto Rico, for 2002. 


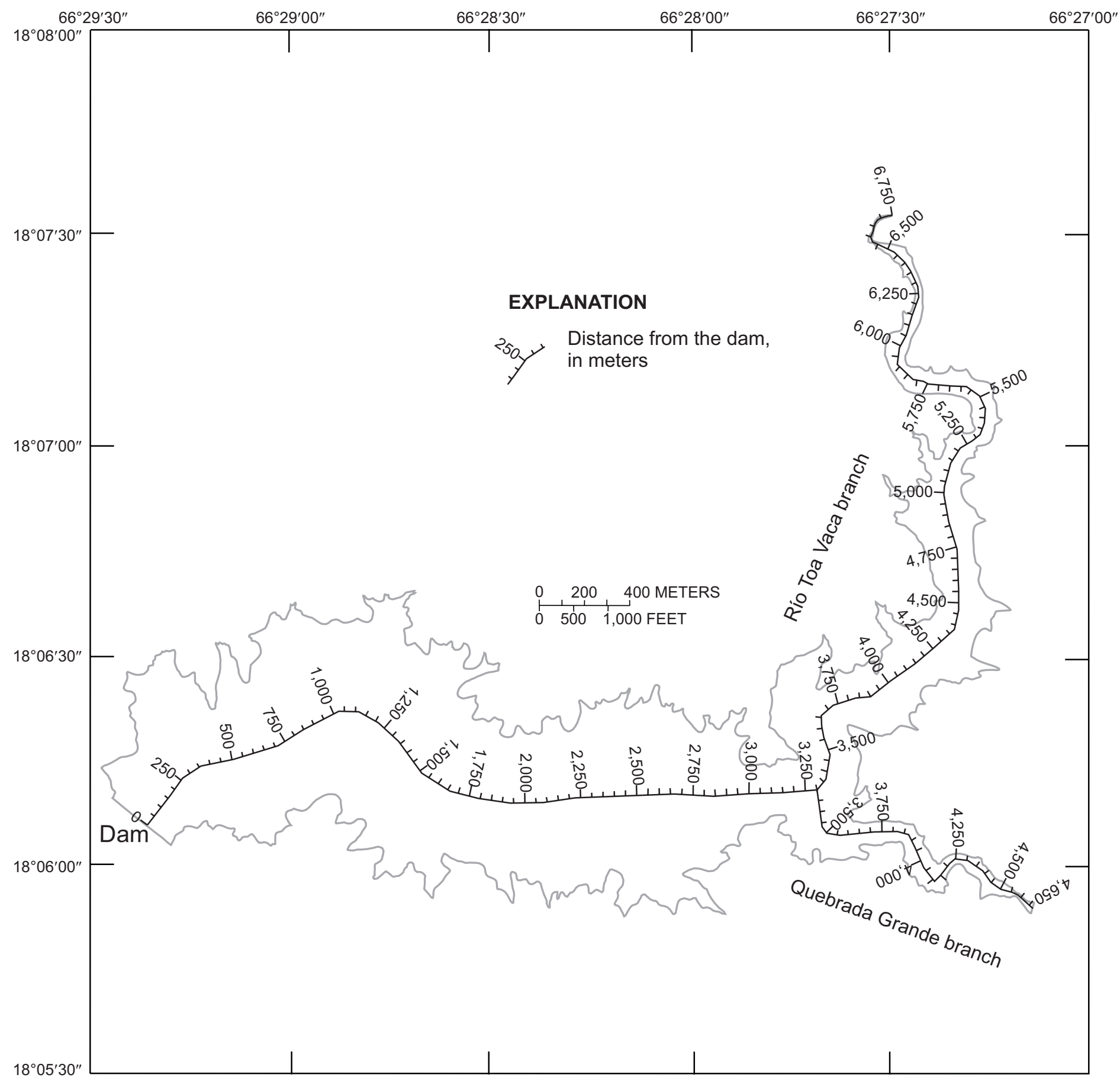

Figure 8. Reference longitudinal distance along the thalweg of Lago Toa Vaca, Puerto Rico. 


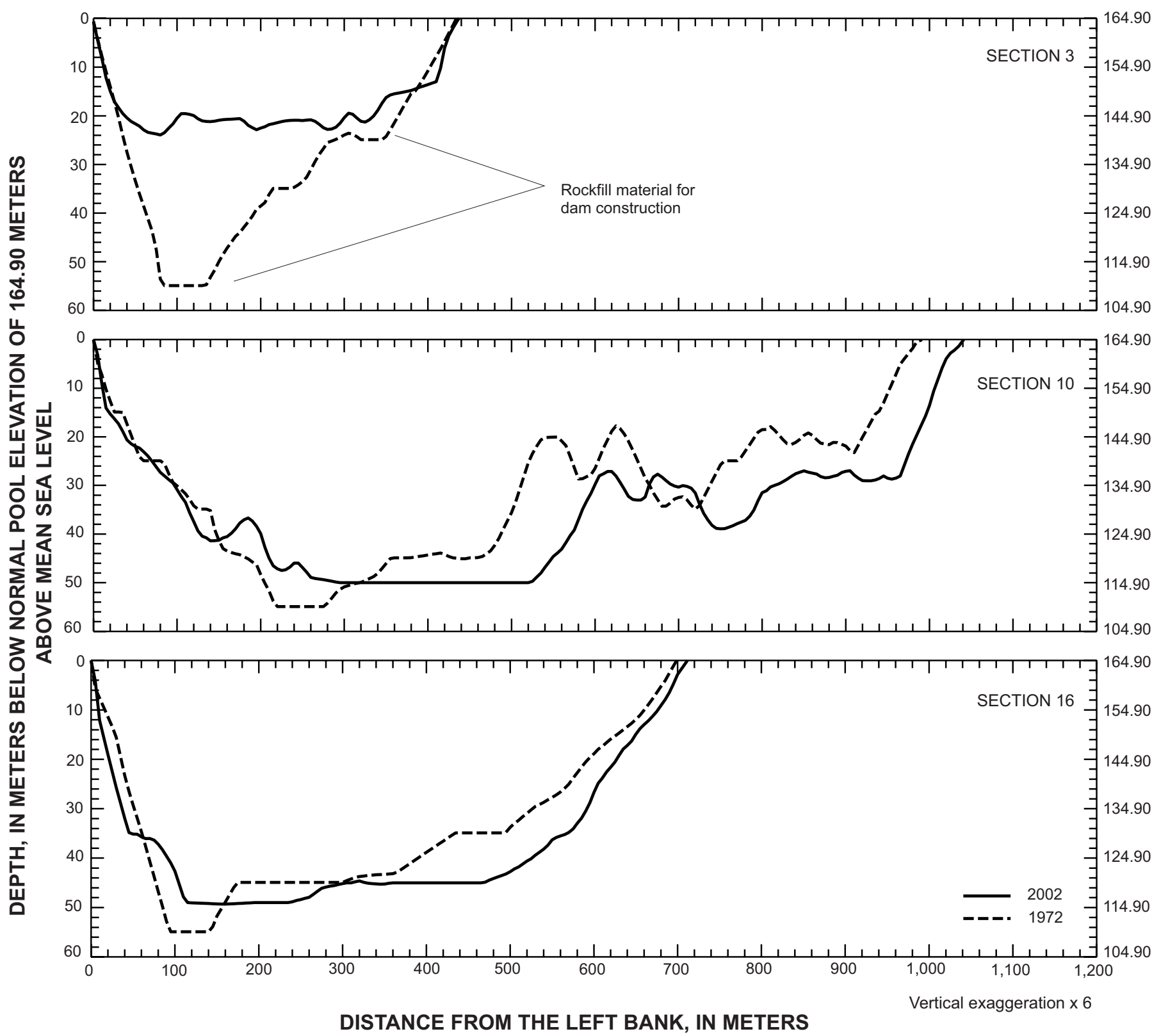

Figure 9. Selected cross sections generated from the TIN surface models of Lago Toa Vaca, Puerto Rico, for 1972 and 2002. Refer to figure 5 for cross-section locations. 


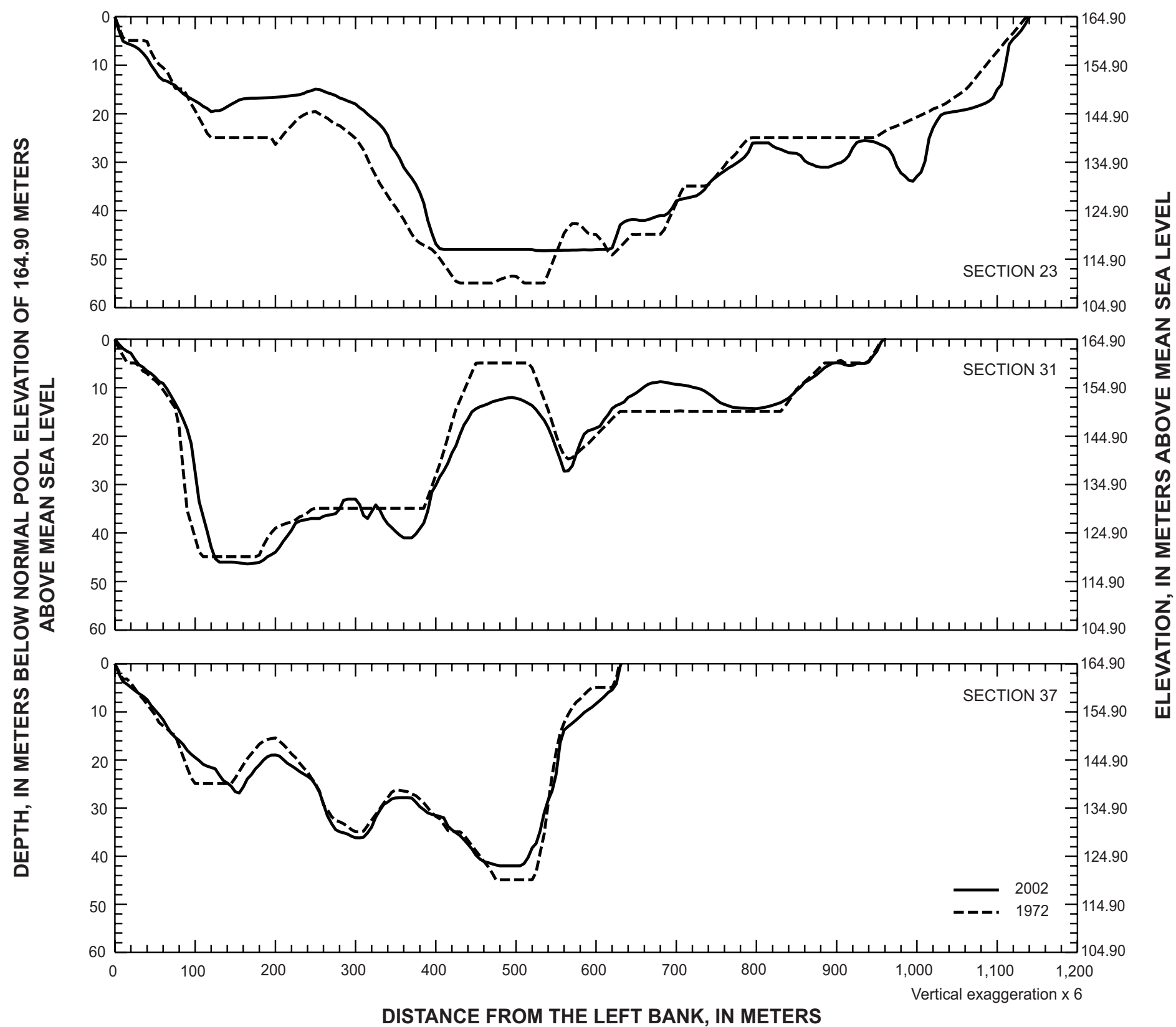

Figure 9. Selected cross sections generated from the TIN surface models of Lago Toa Vaca, Puerto Rico, for 1972 and 2002. Refer to figure 5 for cross-section locations. - Continued 


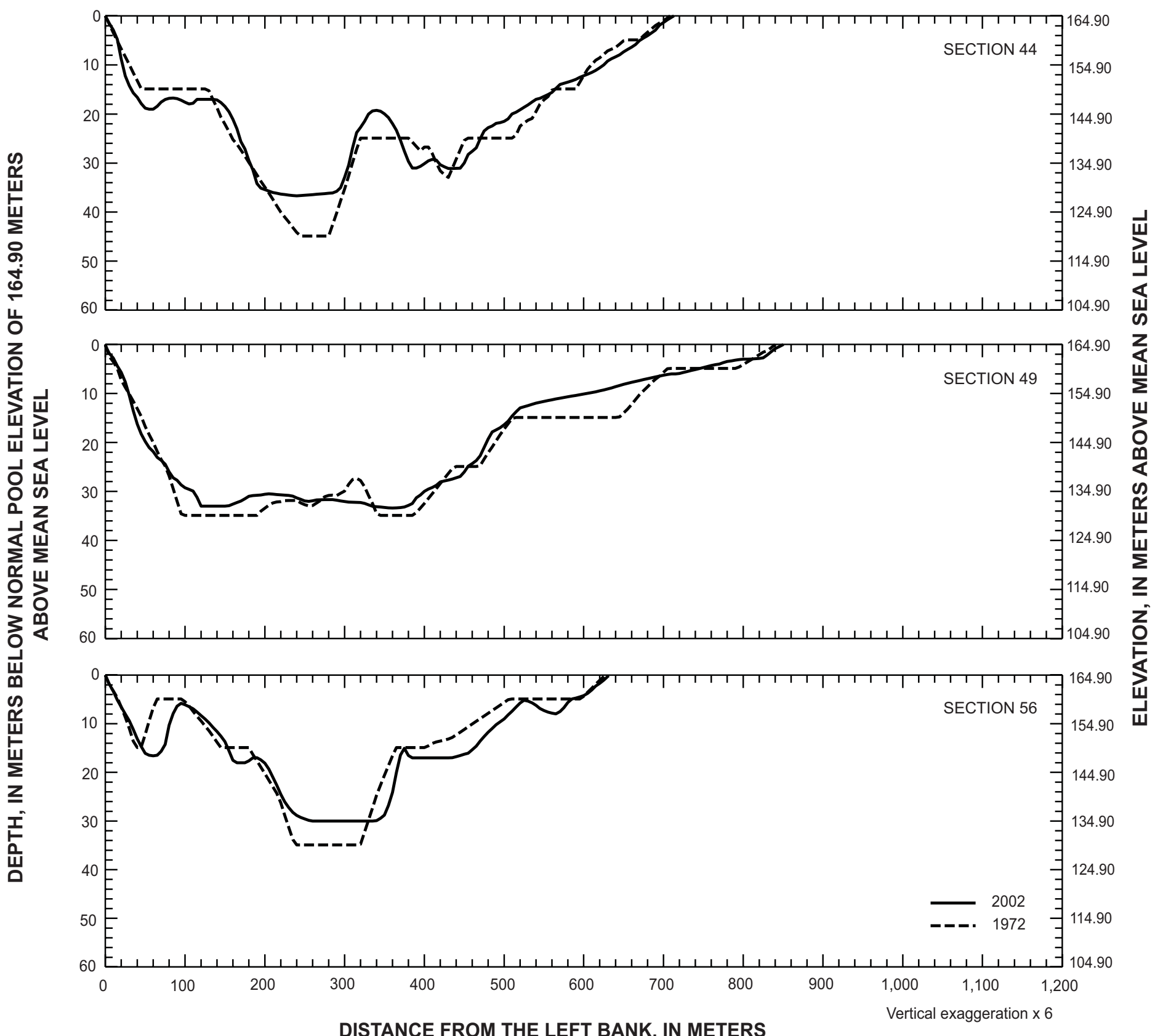

Figure 9. Selected cross sections generated from the TIN surface models of Lago Toa Vaca, Puerto Rico, for 1972 and 2002. Refer to figure 5 for cross-section locations.-Continued 


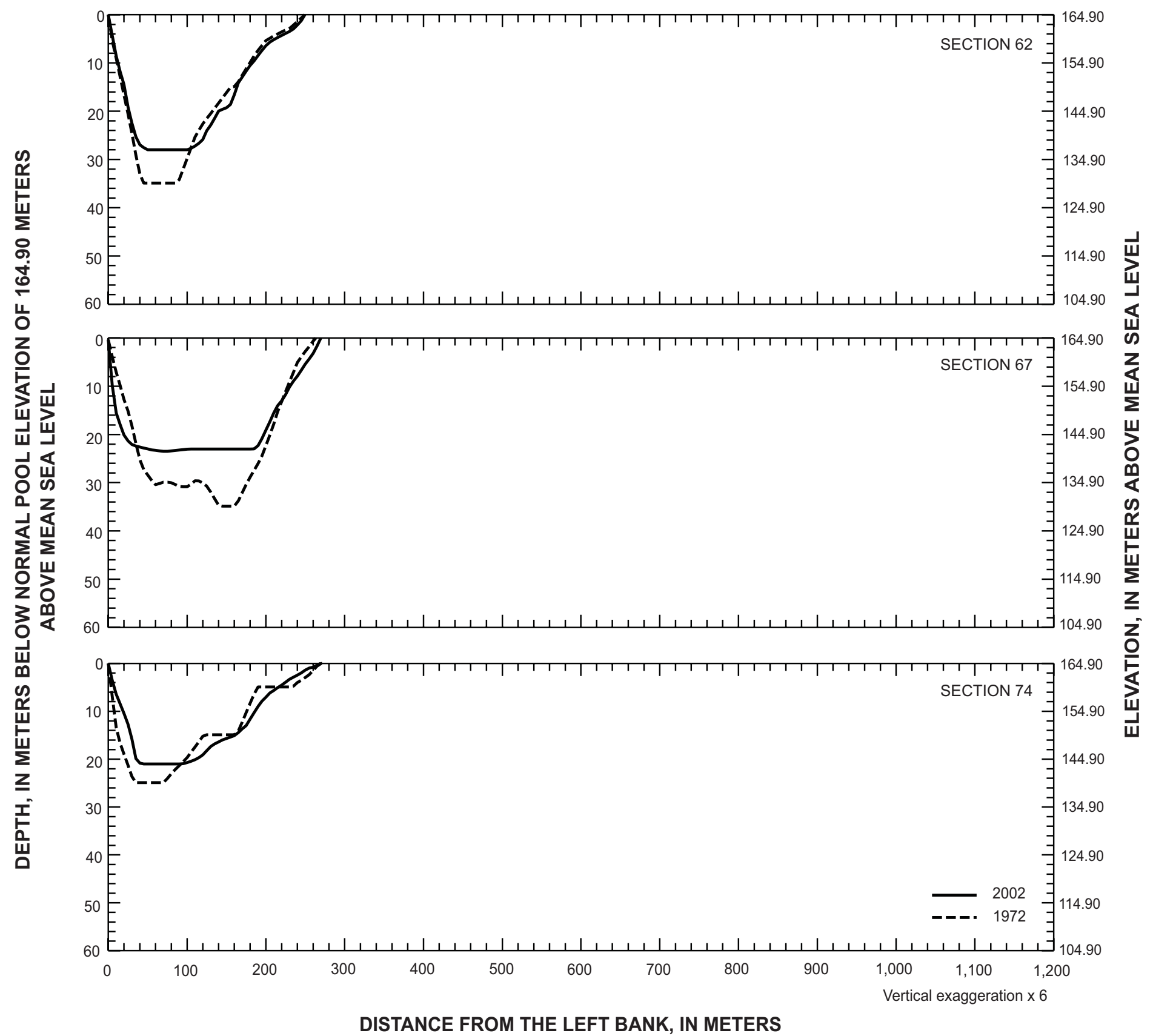

Figure 9. Selected cross sections generated from the TIN surface models of Lago Toa Vaca, Puerto Rico, for 1972 and 2002. Refer to figure 5 for cross-section locations.-Continued 


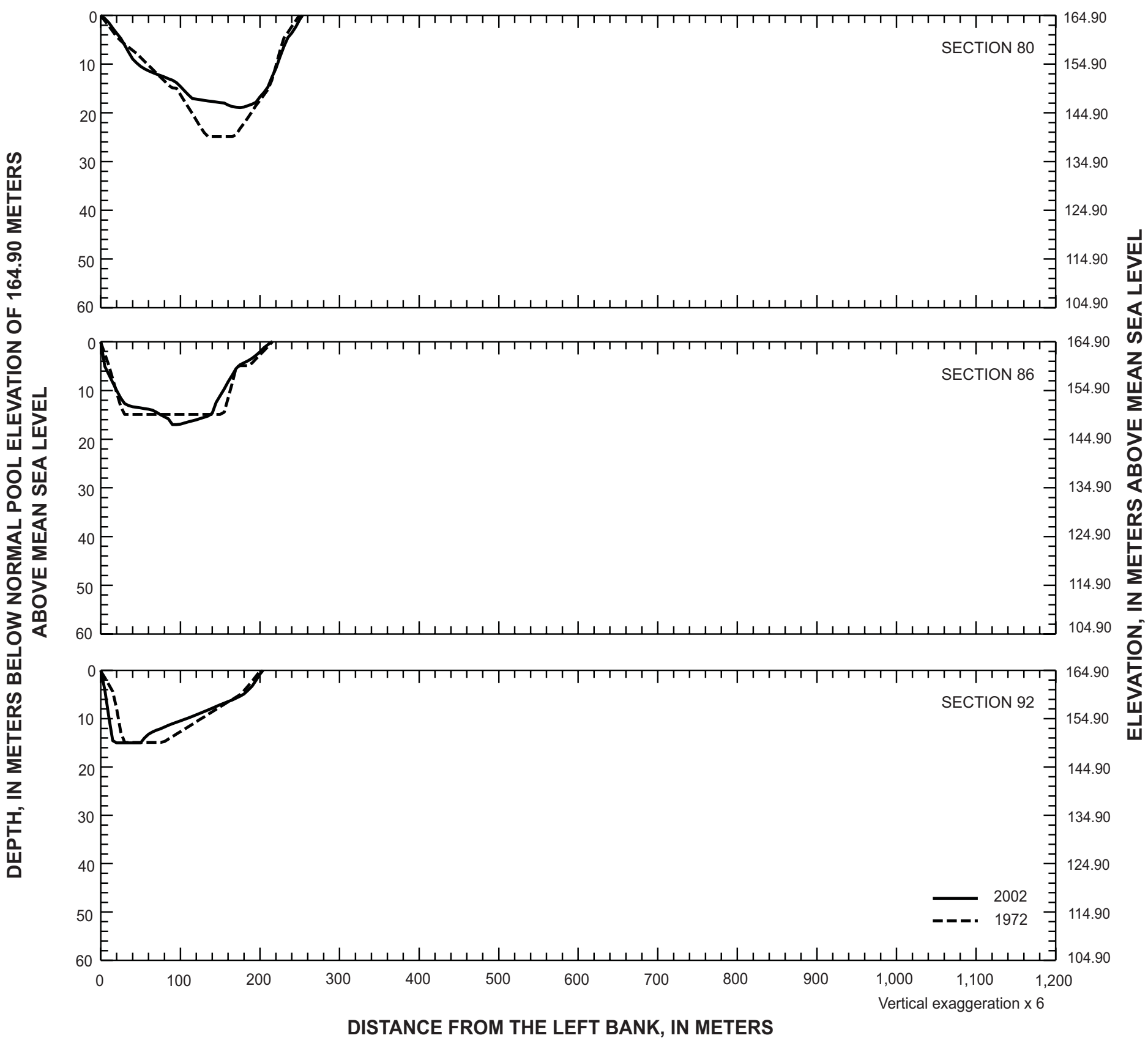

Figure 9. Selected cross sections generated from the TIN surface models of Lago Toa Vaca, Puerto Rico, for 1972 and 2002. Refer to figure 5 for cross-section locations.-Continued 


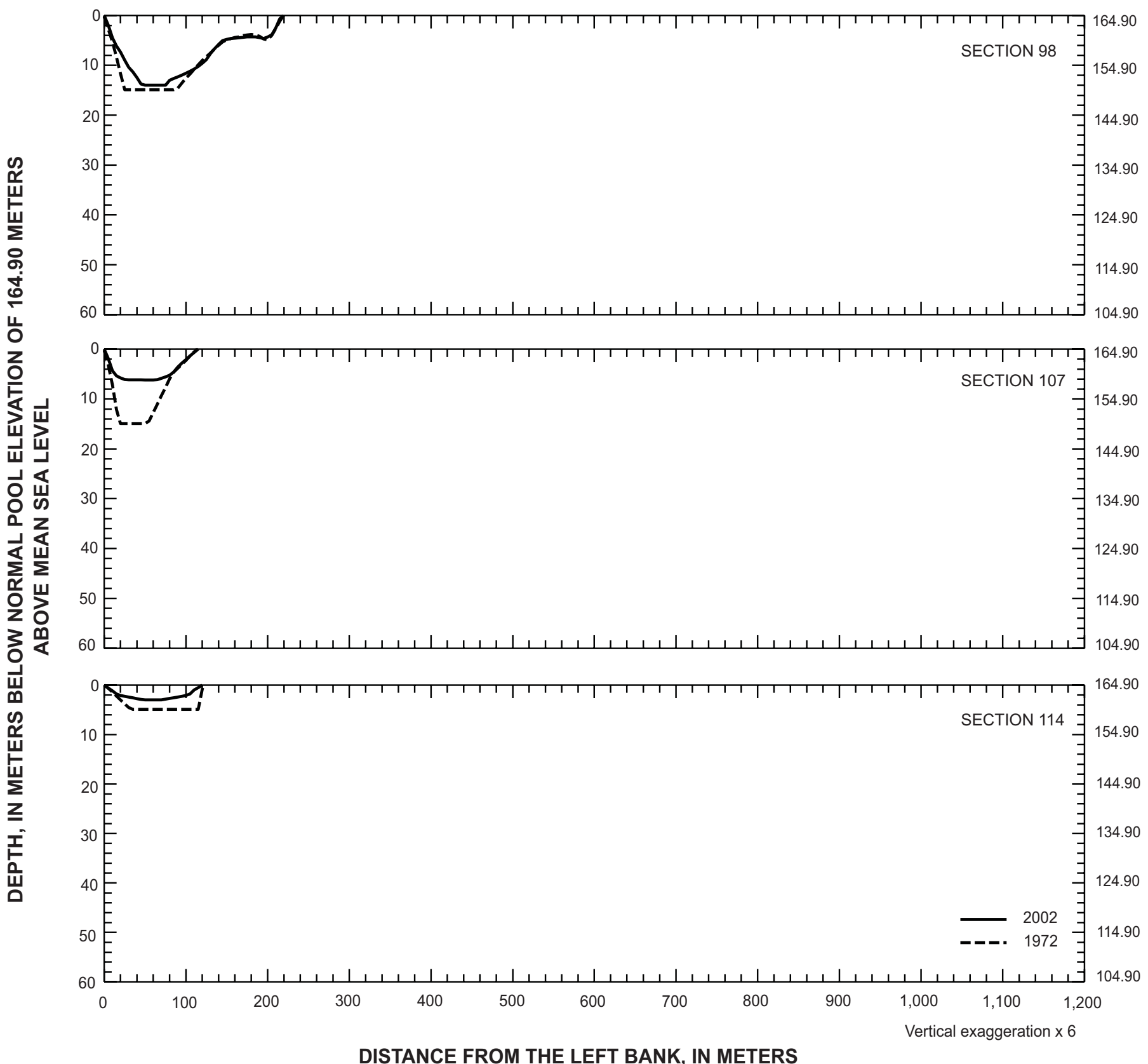

Figure 9. Selected cross sections generated from the TIN surface models of Lago Toa Vaca, Puerto Rico, for 1972 and 2002. Refer to figure 5 for cross-section locations. - Continued 


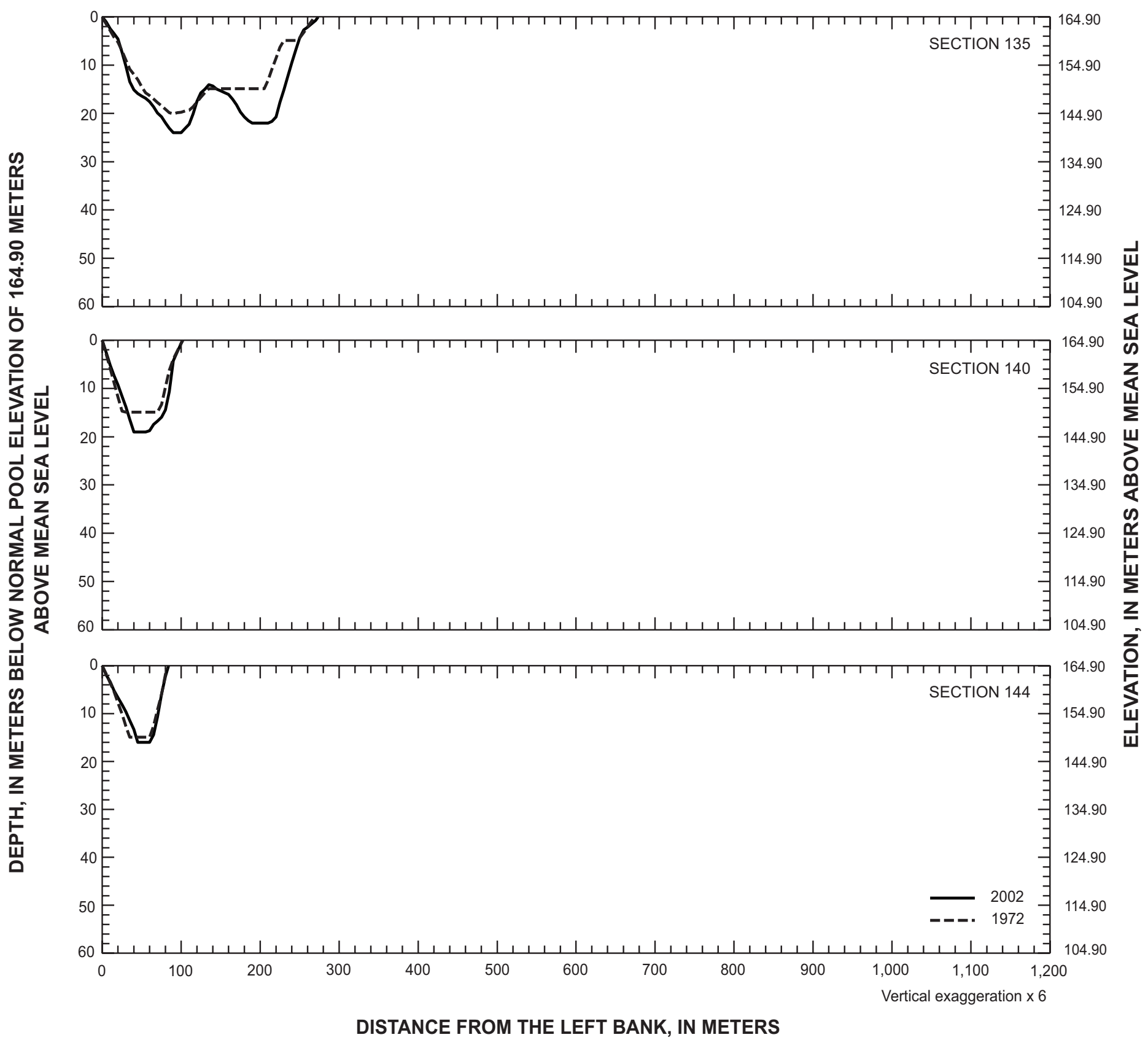

Figure 9. Selected cross sections generated from the TIN surface models of Lago Toa Vaca, Puerto Rico, for 1972 and 2002. Refer to figure 5 for cross-section locations.-Continued 


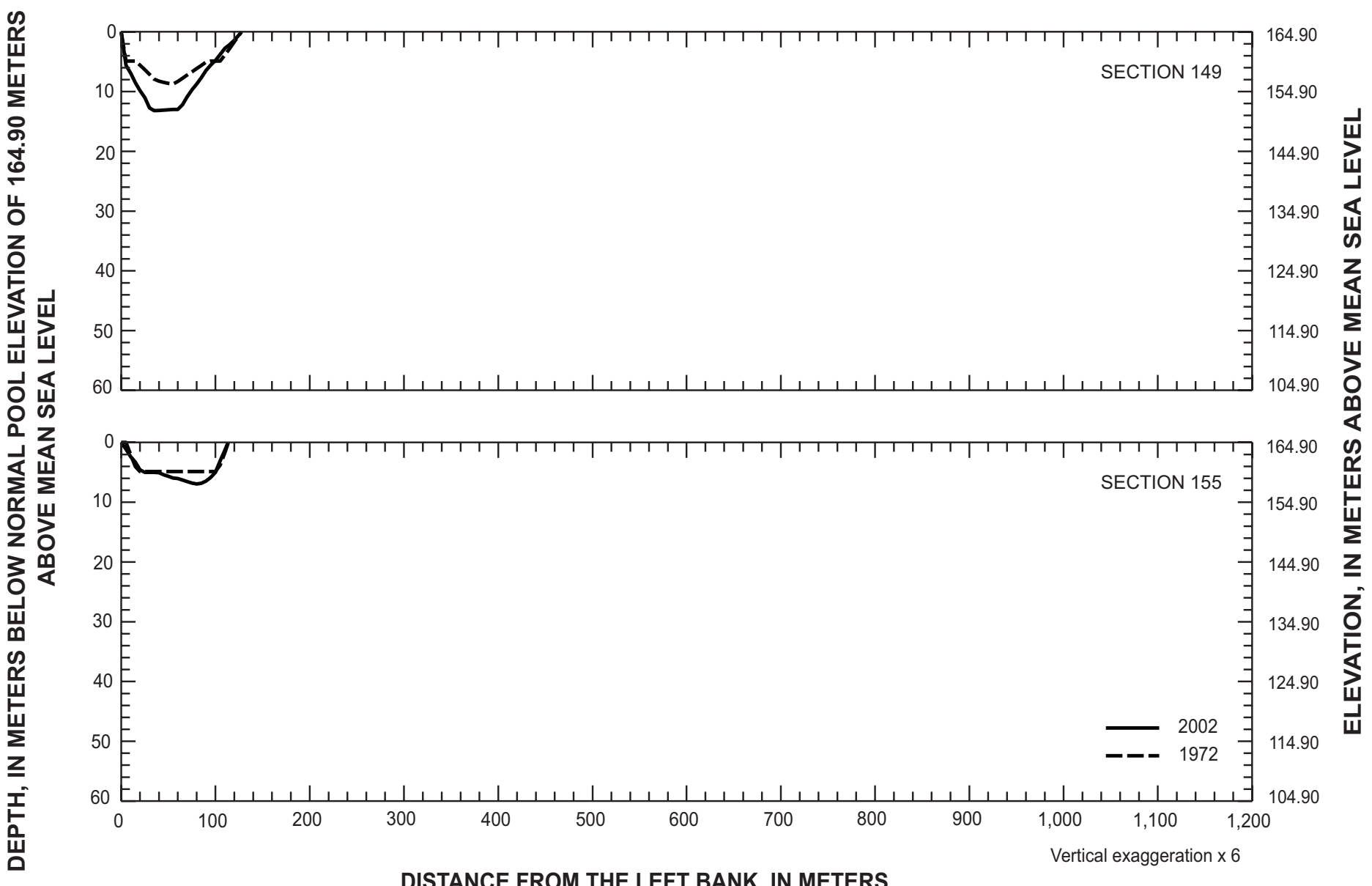

Figure 9. Selected cross sections generated from the TIN surface models of Lago Toa Vaca, Puerto Rico, for 1972 and 2002. Refer to figure 5 for cross-section locations. - Continued 

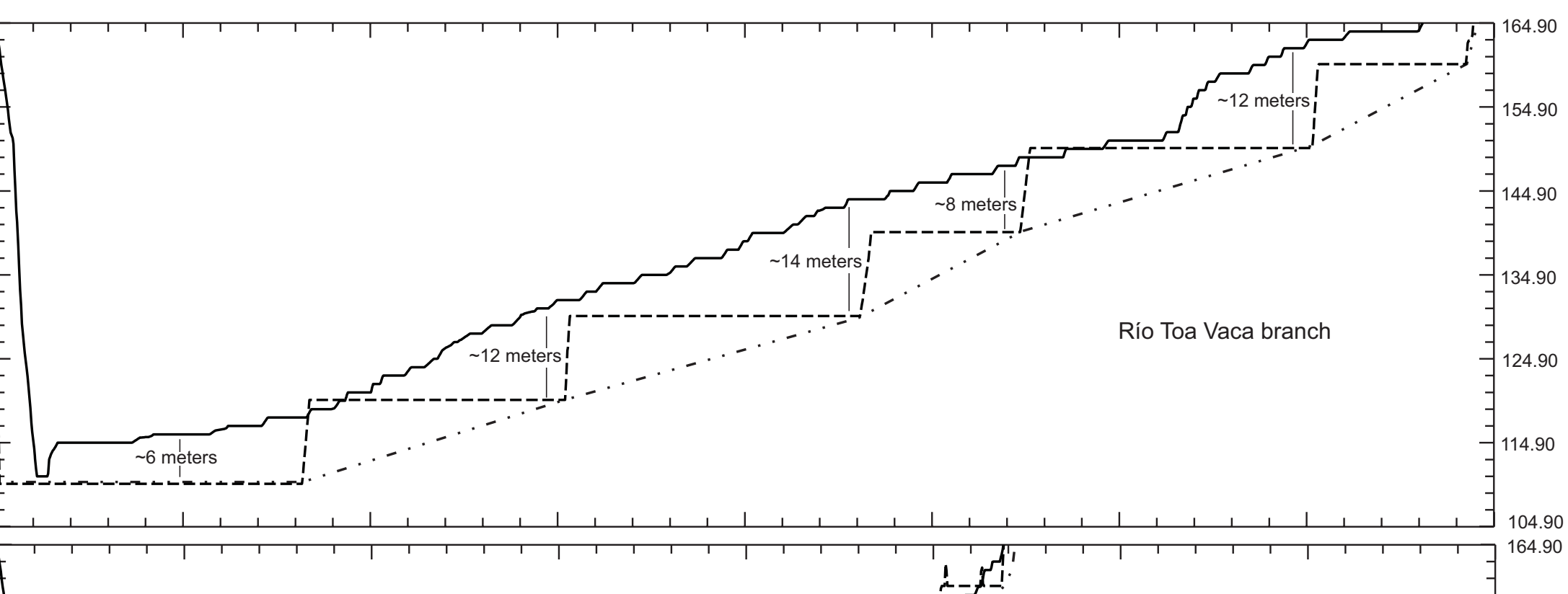

Figure 10. Longitudinal profiles generated from the TIN surface models along the thalweg of Lago Toa Vaca, Puerto Rico, for 1972 and 2002 


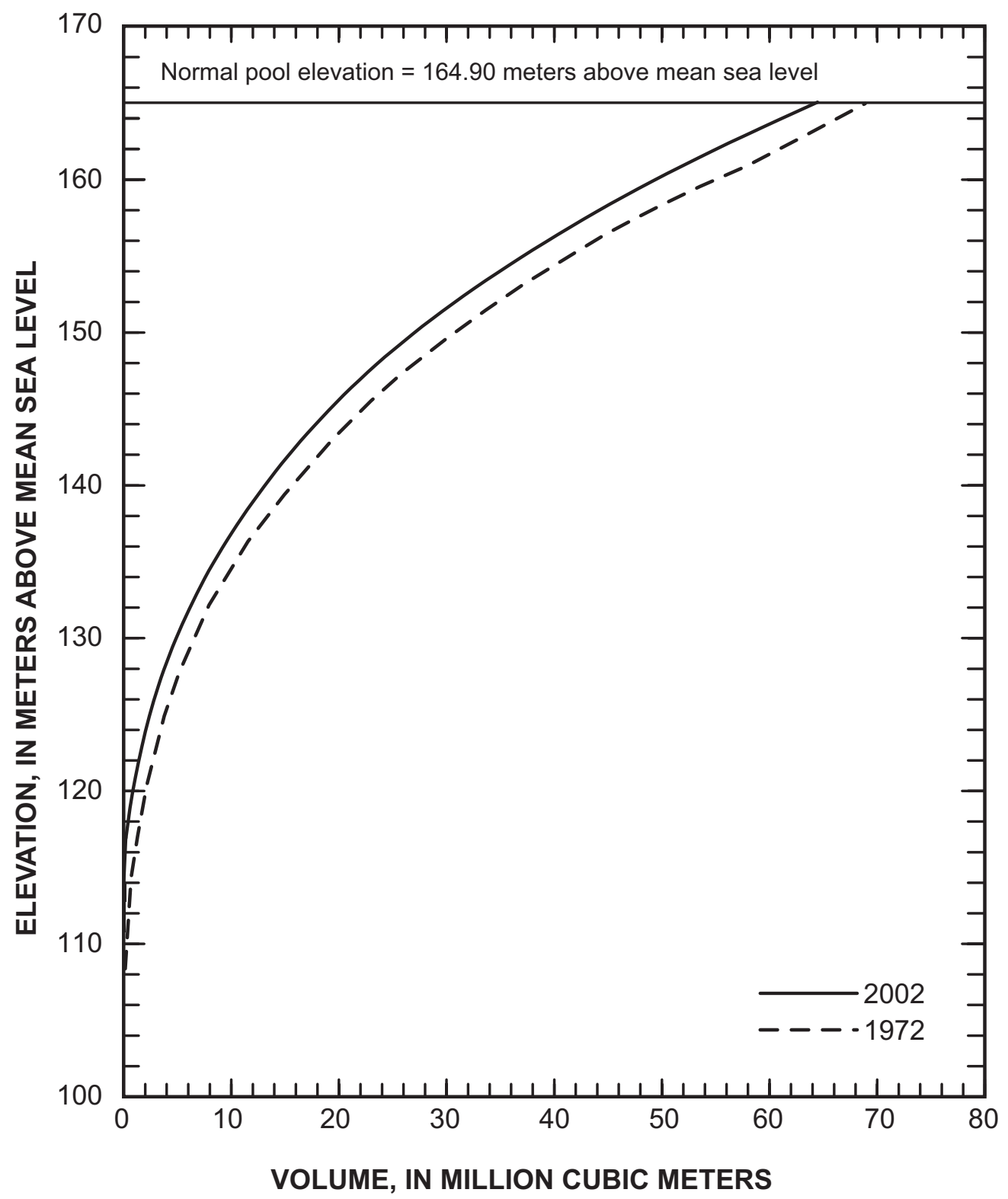

Figure 11. Lago Toa Vaca capacity curves for 1972 and 2002. 


\section{Data Processing}

Initial editing for the 2002 data was performed using the HYPACK software. Positions were corrected to eliminate anomalies that occur when the correction signal from the reference station is lost because of local topographic features or electromagnetic interference. Position errors were corrected by interpolating back to the middle point between the correct anteceding and preceding position. The depth data also were corrected to eliminate incorrect depth readings that can result from insufficient signal gain or when floating debris interferes with the transducer face. Incorrect depth readings were interpolated between the correct anteceding or preceding depth readings. Edited data were then transferred into the Arc/Info GIS database for further processing. The Arc/Info software was customized to color-code the depth data according to different depth intervals. Data points of the same color code were connected by adding a line between them, and a contour map of the reservoir bottom depth was generated (plate 1). The bathymetric contour map (plate 1) was used to create the TIN surface model of the reservoir bottom for 2002 (fig. 7). In addition, the 1972 pre-impoundment topography of Lago Toa Vaca, extracted from the 1:20,000 scale USGS Río Descalabrado topographic quadrangle, was converted into a TIN to re-calculate the original reservoir volume and to generate cross sections and longitudinal profiles.

Sampling the TIN every five meters along selected cross sections generated profiles representing the reservoir bottom from shore to shore for 1972 and 2002 (fig. 9). The same procedure used in generating the selected cross-section profiles was employed to generate the longitudinal profile along the thalweg of Lago Toa Vaca for the same years (fig. 10). The selected cross sections were located to represent flooded areas of the reservoir; whereas the longitudinal profiles were located at the deepest part of the reservoir bottom from the dam upgradient to the river deltas of the tributaries.

The 1972 pre-impoundment topography of Lago Toa Vaca was scanned, geo-referenced (assign real-world coordinates and map projection) and converted into a TIN using the GIS. From this TIN, the 1972 original volume was calculated and yielded a volume of 64.16 million cubic meters or about 0.08 million cubic meters more than the 2002 calculated volume of 64.08 million cubic meters. This minimal volume difference suggests that the reservoir essentially had not sedimented in 30 years, which is unrealistic. The 1972 original pre-impoundment topography of Lago Toa Vaca, obtained from the 1:20,000 USGS Río Descalabrado topographic quadrangle was examined and no apparent error or inconsistency was found. To clarify any discrepancies, the original 1968 pre-impoundment engineering plans and topographic map used for the construction project was requested from the United States Bureau of Reclamation (USBR) to recalculate the original volume using the official project map. This map was essentially the same as the USGS topographic map with the same elevation intervals, with the exception that the USBR map had two distinct areas identified on the map: a rock quarry and a borrow area. These areas were mined to construct the earthfill dam. The storage capacity of the reservoir reported in the USBR map was 68.94 million cubic meters. Therefore, the difference between the 1972 GIS-calculated and the 1968 USBR-reported volume (4.78 million cubic meters) could be the amount of rock and soil material removed from within the impoundment to construct the earthfill dam. The 1975 Puerto Rico Water Resources Authority (PRWRA), Phase I Inspection Report of the National Dam Safety Program informed that the Toa Vaca dam contained 2.17 million cubic meters of material. Therefore, the dam material volumes difference between the GIS calculated and USBR reported probably reflects the compaction of bedrock and soil material used to build the earthfill dam. Evidence of material removal scars was found when the 1968 USBR reservoir shoreline was compared to the 1995 aerial photograph of the near-dam area, and while conducting the 2002 bathymetric survey of Lago Toa Vaca (figs. 12, 13, and 14).

\section{Storage Capacity and Sediment Accumulation}

The Lago Toa Vaca reservoir has been affected by a moderate sediment load and consequent storage loss since its construction in 1972. The storage capacity has decreased from 68.94 million cubic meters in 1972 to 64.08 million cubic meters in 2002 or a total storage loss of 7 percent. The amount of sediment accumulated indicates an annual sedimentation or storage loss rate of 162,000 cubic meters per year, which represents an annual loss of 0.23 percent of the original reservoir volume.

A sedimentation survey conducted by the USGS in 1985 indicated a reservoir volume of 62.44 million cubic meters compared to the 2002 volume of 64.08 million cubic meters (Figueroa-Alamo, 1991). This apparent increase in reservoir volume is unrealistic because no sediment removal activities were performed between 1985 and 2002.

A detailed analysis of the 1985 bathymetric survey data indicates two possible causes for the apparent unrealistic increased storage: (1) that survey used the maximum pool elevation volume as the baseline reference instead of the normal conservation pool elevation volume as the original storage capacity for the calculations, the sediment accumulation and storage loss are over-estimated and, (2) the 1985 bathymetric survey used only 31 cross sections in the computations compared to the 114 cross sections surveyed during 2002 (fig. 15). From figure 15 it is evident that more than 1,500 meters of the Río Toa Vaca branch, and more than 500 meters of the Quebrada Grande branch were not surveyed, therefore, a substantial water volume was unaccounted-for resulting in an underestimation of storage capacity for 1985 . For these reasons the 1985 survey was not included in the analysis of the data in this report. Table 2 shows a comparison of the 1972 topographic survey with the 2002 bathymetric survey results. 


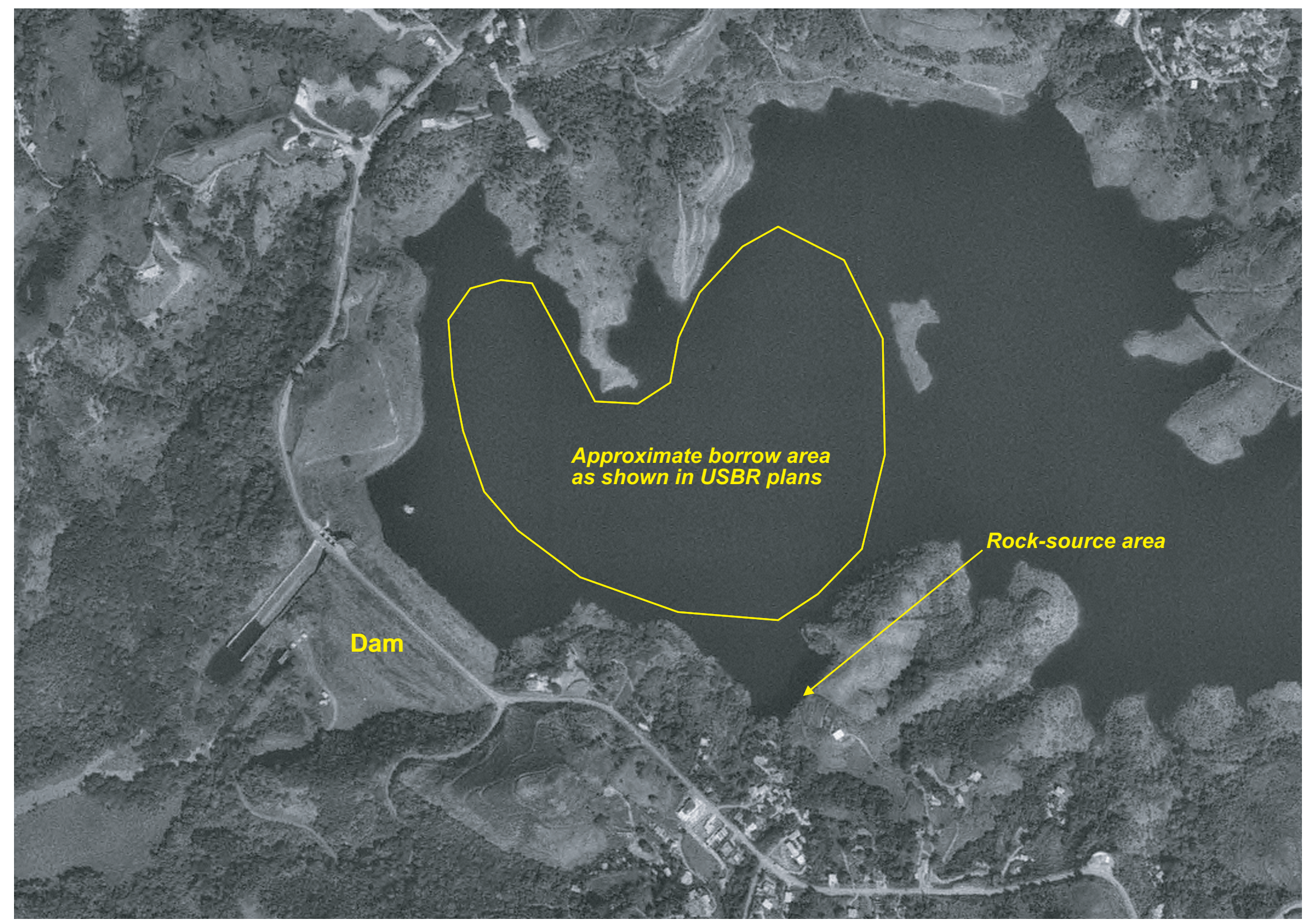

Figure 12. Aerial photograph of the Lago Toa Vaca dam area showing the approximate extent of the borrow area used in construction of the earthfill dam as shown in the Unites States Bureau of Reclamation plans. 


\section{EXPLANATION}

Pre-impoundment shoreline

Impoundment shoreline

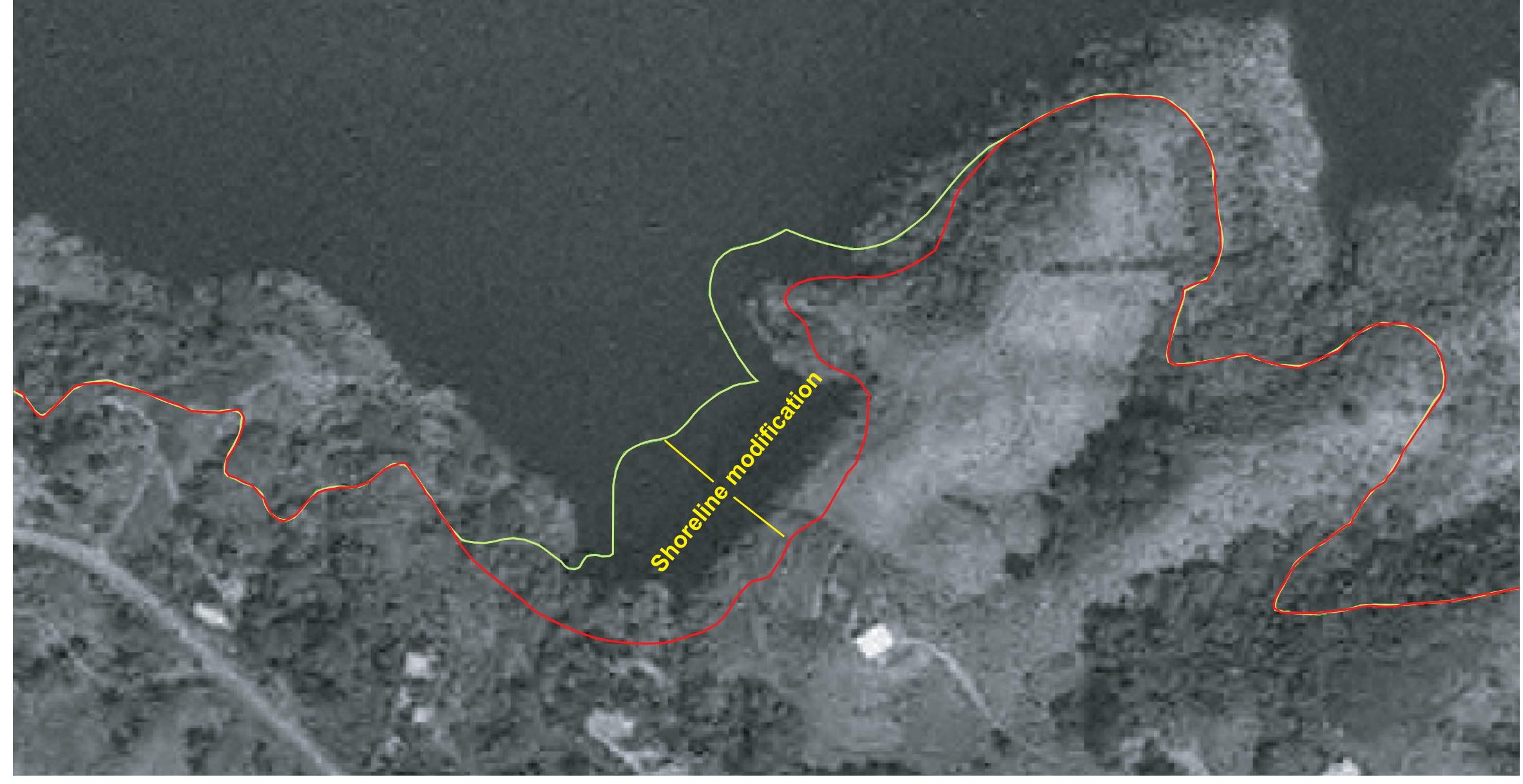

Figure 13. Aerial photograph of the Lago Toa Vaca dam area showing the rock-source area and the resulting new shoreline. 

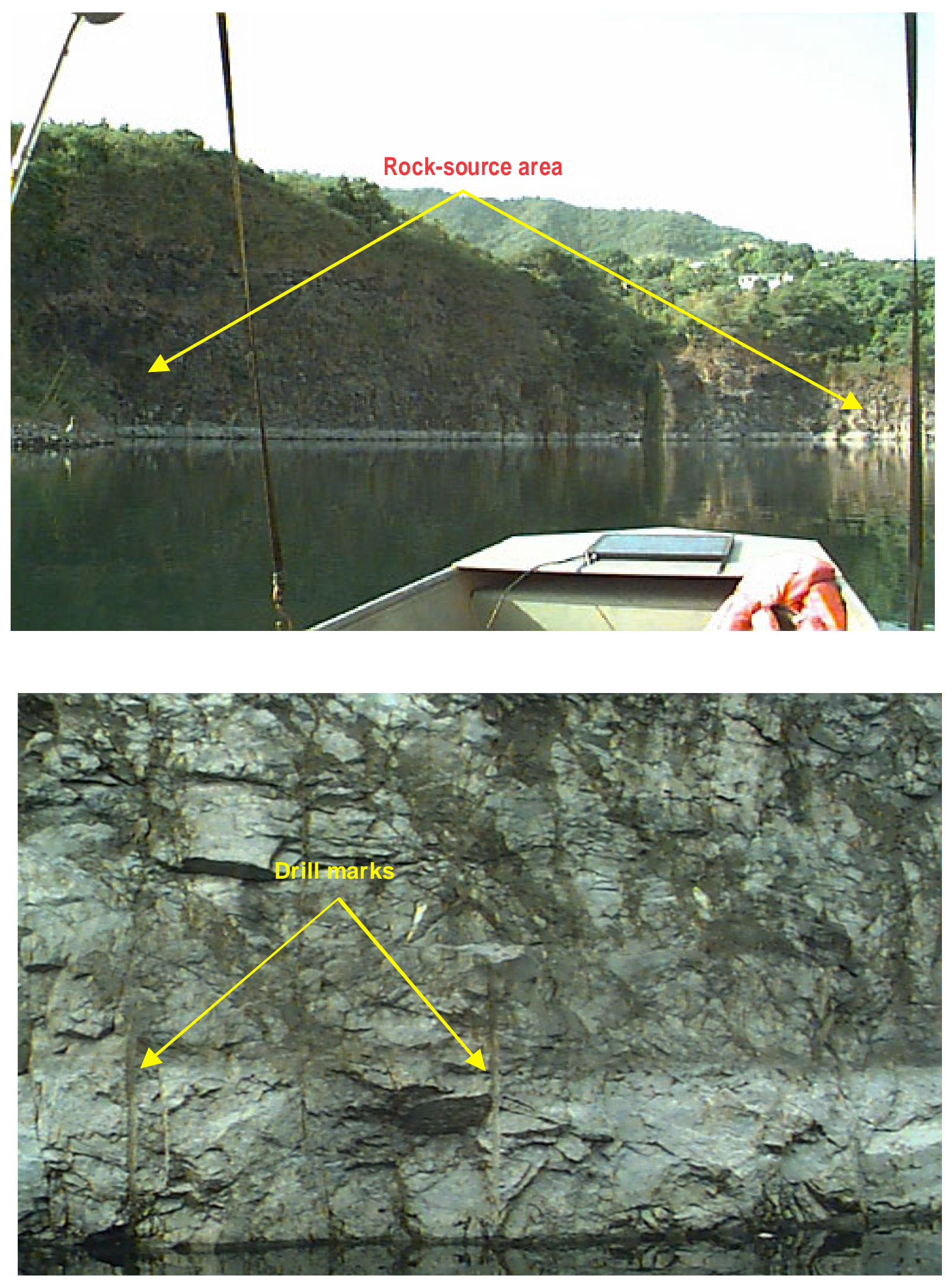

Figure 14. Front-view perspective of the rock-source area and drill marks visible during the 2002 bathymetric survey of Lago Toa Vaca, Puerto Rico. 


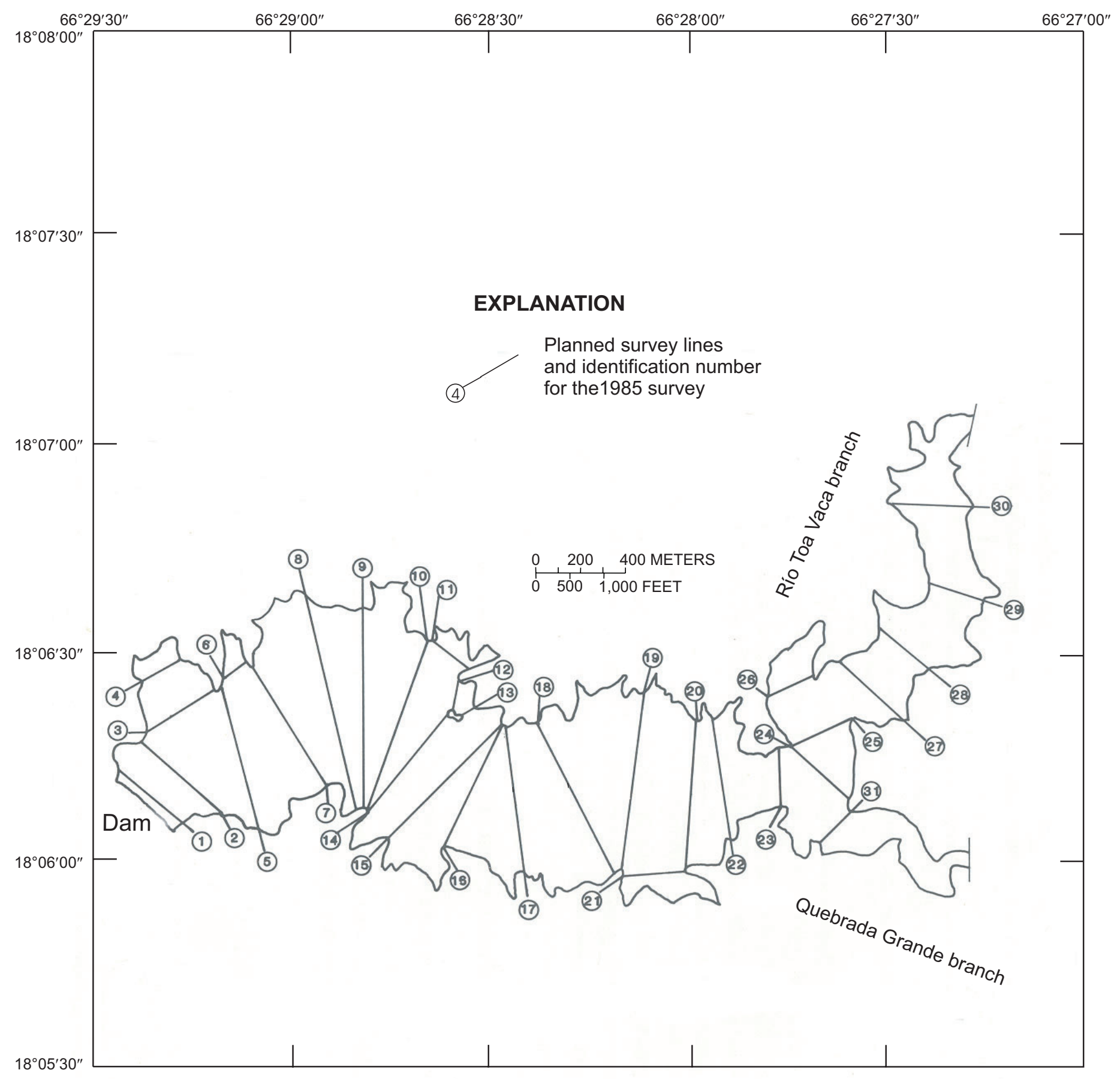

Figure 15. Planned location of sounding lines for the 1985 bathymetric survey of Lago Toa Vaca, Puerto Rico. 
Table 2. Comparison of the 1972 topographic survey with the 2002 bathymetric survey of Lago Toa Vaca, Puerto Rico.

[---, undetermined]

\begin{tabular}{lcc}
\hline \multicolumn{1}{c}{ Year } & 1972 & 2002 \\
\hline Drainage area at dam site, in square kilometers & 56.8 & 56.8 \\
Reservoir surface area, in square kilometers & 3.19 & 3.22 \\
Storage capacity, in million cubic meters & 68.94 & 64.08 \\
Live storage, in million cubic meters & 64.01 & 62.86 \\
Dead storage, in million cubic meters & 4.93 & 3.22 \\
Years since construction & 0 & 30 \\
Sediment accumulated, in million cubic meters & 0 & 4.86 \\
Long-term storage loss, in percent & 0 & 7 \\
Long-term annual loss of capacity, in cubic meters & 0 & 162,000 \\
Long-term annual loss of capacity, in percent & 0 & 0.23 \\
Drainage area runoff, in million cubic meters ${ }^{1}$ & --- & 21.63 \\
Storage capacity to annual inflow ratio & 21.63 & 3.19 \\
Trapping efficiency, in percent & 99 & 98
\end{tabular}

\footnotetext{
${ }^{1}$ Represents the historically measured runoff into Lago Toa Vaca.
}

The Lago Toa Vaca reservoir has 6 water-intake structures used for potable water withdrawals. The tower is located about 130 meters upstream from the spillway, faces upstream, and is oriented in the northeastern direction. These intakes are at invert elevations of $121.00,124.05,132.59,141.73,150.88,160.02$ meters above mean sea level, respectively. The invert elevation refers to the elevation of the lowest portion of the water intake.

The volume of water contained above the elevation of the operational intake structure is referred to as the live (useful) storage and the volume below it is referred to as the dead storage (the dead storage is designed to accommodate sediment without disabling reservoir structures). The 2002 bathymetric data indicate that the reservoir bottom in the vicinity of the water intake tower was at an approximate elevation of 118.90 meters above mean sea level. This suggests that all of the water intakes are operational and that the bed of the reservoir is about two meters below the invert elevation of the lowest intake structure. Using the lowest operational intake structure invert elevation of 121.00 meters above mean sea level, the live storage of Lago Toa Vaca is about 62.86 million cubic meters and the dead storage is about 1.22 million cubic meters. The storage capacity of Lago Toa Vaca at 1-meter elevation intervals is listed in table 3 .

The longitudinal bottom profiles "stairs-like" shape of the 1972 pre-impounded topography of Lago Toa Vaca (fig. 10) is the result of an artifact of the Arc/Info TIN-generating software. The program is instructed to generate the bottom profile from the deepest to the shallowest areas of the reservoir. Thus, the program starts generating the profile at the dam portion of the reservoir and continues upstream towards the river deltas.

Because the topographic contour intervals of the 1972 map is 10 meters; there is considerable distance between the contour values; therefore, the software maintains the previous value until it finds the next corresponding value resulting in a stairslike bottom profile. Therefore, the reservoir bottom profile slope and shape is better illustrated by interpolating the preceding and subsequent contour values (fig. 10, adjusted bottom profile). 
28 Sedimentation Survey of Lago Toa Vaca, Puerto Rico, June-July 2002

Table 3. Storage capacity of Lago Toa Vaca, Puerto Rico, June-July 2002. [all elevations in meters above mean sea level, all capacities in million cubic meters]

\begin{tabular}{|c|c|c|c|}
\hline Pool elevation & Storage capacity & Pool elevation & Storage capacity \\
\hline 164.90 & 64.08 & 137.90 & 11.09 \\
\hline 163.90 & 60.91 & 136.90 & 10.15 \\
\hline 162.90 & 57.84 & 135.90 & 9.26 \\
\hline 161.90 & 54.87 & 134.90 & 8.42 \\
\hline 160.90 & 52.00 & 133.90 & 7.63 \\
\hline 159.90 & 49.23 & 132.90 & 6.89 \\
\hline 158.90 & 46.58 & 131.90 & 6.20 \\
\hline 157.90 & 44.04 & 130.90 & 5.54 \\
\hline 156.90 & 41.60 & 129.90 & 4.92 \\
\hline 155.90 & 39.25 & 128.90 & 4.35 \\
\hline 154.90 & 36.99 & 127.90 & 3.82 \\
\hline 153.90 & 34.81 & 126.90 & 3.34 \\
\hline 152.90 & 32.71 & 125.90 & 2.90 \\
\hline 151.90 & 30.70 & 124.90 & 2.50 \\
\hline 150.90 & 28.78 & 123.90 & 2.12 \\
\hline 149.90 & 26.96 & 122.90 & 1.78 \\
\hline 148.90 & 25.22 & 121.90 & 1.48 \\
\hline 147.90 & 23.57 & 120.90 & 1.20 \\
\hline 146.90 & 22.01 & 119.90 & 0.94 \\
\hline 145.90 & 20.54 & 118.90 & 0.70 \\
\hline 144.90 & 19.14 & 117.90 & 0.49 \\
\hline 143.90 & 17.82 & 116.90 & 0.31 \\
\hline 142.90 & 16.55 & 115.90 & 0.16 \\
\hline 141.90 & 15.35 & 114.90 & 0.06 \\
\hline 140.90 & 14.21 & 113.90 & 0.04 \\
\hline 139.90 & 13.12 & 112.90 & 0.02 \\
\hline \multirow[t]{2}{*}{138.90} & 12.08 & 111.90 & 0.005 \\
\hline & & 110.90 & 0.000 \\
\hline
\end{tabular}


The long-term sediment accumulation after 30 years of reservoir impoundment is not uniform. By nature, the morphology of a reservoir bottom immediately after impoundment is wedge-shaped, very similar to the topographic relief of the surrounding hill slopes. Thus, it provides little submerged surface area for sediment deposition and sediment accumulates rapidly and vertically at a relatively fast rate. After years of sediment accumulation, the topographic relief of the impounded area reshapes from a wedge to a trapezoidal-shaped surface; therefore, sediment accumulation occurs over a larger area and the rate at which water depth decreases with time due to sediment accumulation is lower. This apparent non-uniform long-term reduction of depth is more evident in reservoirs that are surveyed on a more frequent basis (Webb and Soler-López, 1997).

Along the Río Toa Vaca branch, the profile presented on figure 10 indicates that a 6-meter thick layer of sediment has accumulated from the base of the dam to about 1,000 meters upstream. A more uniform thickness ranging from 12 to 14 meters of sedimentation extends from about 1,500 meters to a distance of about 4,500 meters upstream from the dam. A sediment layer about 8 meters thick, between a distance of 5,000 and 6,500 meters, and a layer of about 12 meters thick about 6,900 meters upstream from the dam have accumulated. In the riverine portion of the Río Toa Vaca tributary, about 4 meters of sediment have been deposited. The long-term sediment deposition rates in these same segments are: 20,40, 30,40 , and 13 centimeters per year, respectively, averaging about 30 centimeters per year over the entire branch.

On the Quebrada Grande branch, sediment deposition patterns are the same as in the Río Toa Vaca branch to about 3,200 meters upstream from the dam (fig. 10). At about 4,100 meters upstream from the dam; the total thickness of sediment is about 15 meters, and in the riverine portion of the branch, the sediment layer is about 5 meters thick. The deposition rates in the Quebrada Grande branch averages about 26 centimeters per year. At the historical sediment deposition rate of about 20 centimeters per year near the dam, the reservoir bottom in the vicinity of the water intakes could reach the lowest intake in about 10 years (by 2010).

\section{Sediment Trapping Efficiency and Water Renewal Rates}

Heinemann (1981) considered trapping efficiency to be the most informative descriptor of a reservoir. This value is the proportion of the incoming sediment that is deposited or trapped in a pond, reservoir or lake. Trapping efficiency is dependent on several parameters, including sediment particle size distribution, the time and rate of water inflow to the reservoir, the reservoir size and shape, the location of the outlet structure, and discharge schedules (Verstraeten and Poesen, 2000).
Many empirical studies showing the relation between reservoir storage capacity, water inflow, and trapping efficiency have been conducted in the past, of which Brune's (1953) is the most widely used and accepted. Brune (1953) developed a curve (fig. 16) that estimates the trapping efficiency of a reservoir based on the ratio of storage capacity to annual water inflow volume. The trapping efficiency of Lago Toa Vaca was estimated using the relation established by Brune (1953).

Although the Lago Toa Vaca drainage area has a streamgaging station on the Río Toa Vaca tributary with 13 years of continuous record (USGS station Río Toa Vaca above Lago Toa Vaca, Puerto Rico, number 50110900), the station accounts for only 36.8 of the entire 56.8 square-kilometer basin of Lago Toa Vaca, which leaves 20 square kilometers ungaged. The mean-annual runoff for the 36.8 square-kilometer drainage area above the stream-gaging station for the 13 years of record (water years 1989 to 2001) is 14.17 million cubic meters. If the same ratio of runoff to drainage area is applied to the adjacent ungaged Quebrada Grande tributary (20 square kilometers), the annual runoff from this portion is 7.46 million cubic meters. Therefore, the estimated long-term mean-annual runoff for the entire Lago Toa Vaca drainage area is 21.63 million cubic meters.

An alternative method of estimating how much rainfall becomes runoff into the Lago Toa Vaca drainage area, is to use regional correlations developed for drainage basins in Puerto Rico (Giusti and López, 1967) to estimate the average ratio of runoff to rainfall (runoff/rainfall). For the Toa Vaca Basin, this ratio can be estimated as 0.23 . Thus, multiplying the meanannual rainfall of 1,778 millimeters (Calvesbert, 1970) of the Lago Toa Vaca basin by the runoff/rainfall ratio of 0.23 , the estimated mean-annual runoff for the Lago Toa Vaca basin is 409 millimeters. This number multiplied by the 56.8 square kilometer drainage area of Lago Toa Vaca, yields an estimated mean annual inflow to the reservoir of 23.23 million cubic meters, which is in close agreement with the measured 21.63 million cubic meters obtained by using the USGS streamgaging station data. The measured mean-annual runoff into the Lago Toa Vaca of 21.63 million cubic meters was used for the trapping efficiency calculations.

With an original (1972) storage capacity of 68.94 million cubic meters and a present (2002) storage capacity of 64.08 million cubic meters, the ratio of storage capacity to inflow is 3.19 for 1972 and 2.96 for 2002. Using the median curve of Brune's (1953) relation (fig. 16), and the corresponding capacity to inflow ratio, the estimated trapping efficiency of Lago Toa Vaca was 99 and 98 percent for 1972 and 2002, respectively. However, according to Brune's empirical relation the trapping efficiency of a reservoir will decrease as sediment fills the reservoir and lowers the storage capacity. Therefore, with a long-term storage capacity loss of only 0.23 percent per year, the trapping efficiency of Lago Toa Vaca will remain high into the forseeable future. 


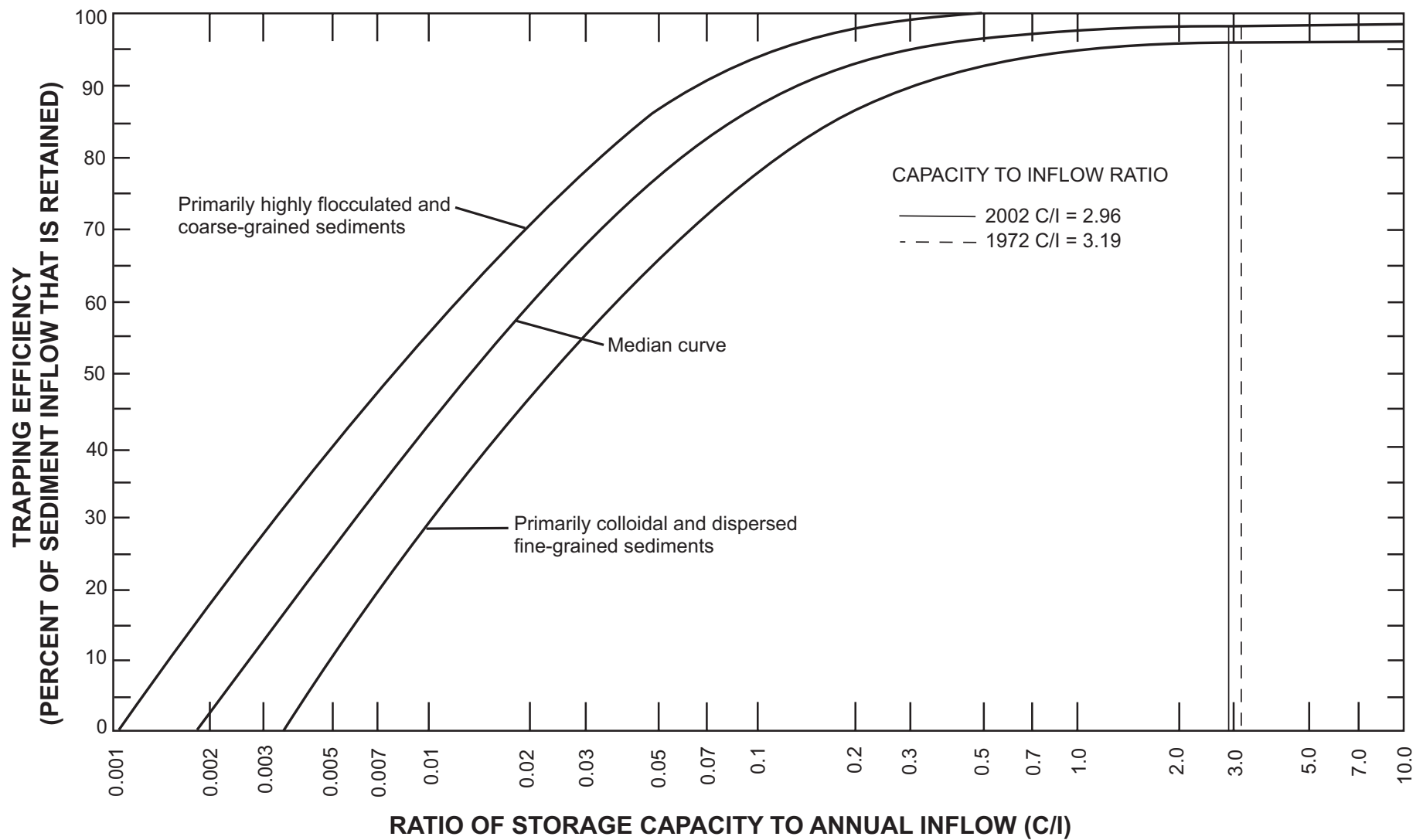

Figure 16. Reservoir trapping efficiency as a function of the ratio between storage capacity and annual water inflow volume. 
Taking into consideration that the storage capacity of Lago Toa Vaca was to receive water from intra-basin transfers, it was designed with a storage capacity three times larger than the mean-annual runoff of its basin; however, the plans were never completed, and therefore, the pool elevation of Lago Toa Vaca is persistently low. Based on the estimated mean-annual inflow to the reservoir, the Lago Toa Vaca drainage area supplies only about 34 percent of the reservoir water volume, and it would normally take about three years to renew the totality of the water (without taking into account the reservoir water withdrawals).

\section{Sediment Yield and Reservoir Life Expectancy}

Sediment yield has been defined by the American Society of Civil Engineers as the total sediment outflow measurable at a point of reference, for a specified period of time, per unit of surface area (McManus and Duck, 1993). For the period from 1972 to 2002, the total estimated volume of sediment contributed to Lago Toa Vaca from a drainage area of 56.8 square kilometers was estimated to be 4.96 million cubic meters. This volume was estimated by dividing 4.86 million cubic meters of sediment accumulation (the volume loss between 1972 and 2002) by the estimated trapping efficiency of 0.98 for 2002. This estimated rate of sediment influx (4.96 million cubic meters) divided by the years between 1972 and 2002 (30 years), results in an average volume of about 165,333 cubic meters of sediment per year. The sediment volume deposited in the Lago Toa Vaca (165,333 cubic meters per year) divided by the net sediment contributing area of 53.58 square kilometers, (the total drainage area of 56.8 square kilometers minus the 3.22 square kilometer surface area of the reservoir) results in an average basin sediment yield or reservoir storage loss of 3,086 cubic meters per square kilometer per year. An estimate of the sediment yield from the drainage area of Lago Toa Vaca on a mass basis can be obtained by using the sediment dry-bulk density of one gram per cubic centimeter reported for Lago Yahuecas, a reservoir located about 25 kilometers northwest of Lago Toa Vaca (Soler-López and others, 1998). Therefore, the Lago Toa Vaca sediment yield on a mass basis is 3,086 megagrams per square kilometer per year. This drainage area-normalized storage capacity loss of Lago Toa Vaca is more than twice the average of 1,389 cubic meters per square kilometer per year of 14 reservoirs studied in Puerto Rico at different locations, soil-type basins, and rainfall magnitudes (Soler-López, 2001).
The life expectancy of Lago Toa Vaca, or any other reservoir can be estimated by dividing the remaining storage capacity by the annual storage capacity loss. Based on the average reservoir storage loss between 1972 and 2002, the reservoir would be completely silted in about 400 years.

\section{Summary and Conclusions}

The Lago Toa Vaca Dam was constructed in 1972 to increase the water availability for irrigation in the southern coastal plain of Puerto Rico. The southern coastal plain receives an average rainfall of about 900 millimeters per year, an amount insufficient to sustain the cultivation of crops without irrigation. In addition, the reservoir was to be part of a multi-purpose project which included intra-basin tunnels to divert flow to the Toa Vaca reservoir. However, the mega project was cancelled in the 1970's and currently the reservoir receives only the runoff from its drainage basin. At present, public demand for potable water has increased in the region and has put additional pressure on the limited resource. In order to update data on the water storage capacity and the safe yield of Lago Toa Vaca, the U.S. Geological Survey conducted a bathymetric survey of the reservoir during June-July 2002 in cooperation with the Puerto Rico Infrastructure Financing Authority. The bathymetry survey was conducted using state-of-the-art geographic information system and global positioning system technology. The data obtained were analyzed and compared to the 1972 pre-impoundment topography to determine sedimentation rates, sediment location and accumulation, and to predict the useful life of the reservoir

Agricultural land-use practices, mining activities, and events such as wildfires enhance erosion affecting the Lago Toa Vaca storage capacity by increasing sediment accumulation and storage loss. The 2002 bathymetric survey of Lago Toa Vaca indicates that the reservoir has lost 4.86 of an original 68.94 million cubic meters of water storage capacity. This represents a long-term storage loss of 0.23 percent per year. With a current reservoir trapping efficiency of 98 percent, any increase in rural development and land disruption within the Lago Toa Vaca drainage area could result in an increased sediment yield, which is currently 3,086 cubic meters per square kilometer per year, about two and one half times higher than the average rate for other reservoirs in Puerto Rico. At the current long-term sedimentation rate and estimated sediment trapping efficiency, Lago Toa Vaca would be completely silted by the year 2400 . The life expectancy of Lago Toa Vaca is long according to recent data, and sediment accumulation in the reservoir does not present an immediate threat to the continued use of essential reservoir structures. 


\section{References Cited}

Brune, G.M., 1953, Trap efficiency of reservoirs: Transactions of the American Geophysical Union, v. 34, no. 3, p. 407-418.

Calvesbert, R.J., 1970, Climate of Puerto Rico and the U.S. Virgin Islands: U.S. Department of Commerce, Environmental Science Services Administration, 29 p.

Environmental Systems Research Institute, Inc., 1992, Surface modeling with TIN, Surface analysis and display: Environmental Systems Research Institute, Inc., Redlands, California, p. 4-1, 6-1.

Figueroa-Alamo, Carlos, 1991, Sedimentation survey of Lago Toa Vaca, Puerto Rico, July 1985: U.S. Geological Survey Open-File Report 90-189, 9 p.

Gierbolini, R.E., 1979, Soil survey of Ponce area of southern Puerto Rico, U.S. Department of Agriculture, Soil Conservation Service, p. 12-23, 1 pl.

Giusti, E.V., and López, M.A., 1967, Climate and streamflow of Puerto Rico: Caribbean Journal of Science, v. 7, no. 3-4, September-December, 1967, p. 87-93.

Heinemann, H.G., 1981, New sediment trap efficiency curve for small reservoirs, Water Resources Bulletin, v. 7, p. 825830.

McManus, J., and Duck, R.W., eds., 1993, Geomorphology and sedimentology of lakes and reservoirs, in Chapter 6, Reservoir sedimentation rates in the Southern Pennine Region, UK: John Wiley \& Sons, New York, p. 73-92.
Puerto Rico Water Resources Authority, 1967, Feasibility Report: Toa Vaca Dam, p. 67-73.

Puerto Rico Water Resources Authority, 1975, Toa Vaca Dam, Inspection Report: Puerto Rico Aqueduct and Sewer Authority, San Juan Puerto Rico, 11 p.

Soler-López, L.R., Webb, R.M.T., and Pérez-Blair, Francisco, 1998, Sedimentation survey of Lago Yahuecas Puerto Rico, March 1997: U.S. Geological Survey Water-Resources Investigations Report 98-4259, 15 p., 2 pls.

Soler-López, L.R., 2001, Sedimentation survey results of the principal water supply reservoirs of Puerto Rico; in W.F. Sylva (ed.), Proceedings of the Sixth Caribbean Islands Water Resources Congress, Mayagüez, Puerto Rico, February 22 and 23, 2001, unpaginated CD.

U.S. Department of Agriculture, Soil Conservation Service, 1987, Preauthorization Planning Report, Toa Vaca Lake watershed, Puerto Rico, p. 2.

Verstraeten, G., and Poesen, J., 2000, Estimated trap efficiency of small reservoirs and ponds: methods and implications for the assessment of sediment yield: Progress in Physical Geography, v. 24, no. 2, p. 219-251.

Webb, R.M.T., and Soler-López, L.R., 1997, Sedimentation history of Lago Loíza, Puerto Rico, 1953-1994: U. S. Geological Survey Water-Resources Investigations Report 97-4108, 18 p., 9 pls. 
District Chief

Caribbean District

U.S. Geological Survey

Water Resources Division

GSA Center, Suite 400-15

651 Federal Drive

Guaynabo, Puerto Rico 00965-5703 